\title{
Recovery of metals and other beneficial products from coal fly ash: a sustainable approach for fly ash management
}

\author{
Prafulla Kumar Sahoo ${ }^{1,2} \cdot K_{\text {Kangjoo } \mathrm{Kim}^{2}} \cdot$ M. A. Powell ${ }^{3}$ Sk Md Equeenuddin ${ }^{4}$
}

Received: 28 September 2015/Revised: 23 February 2016/Accepted: 5 March 2016/Published online: 19 August 2016

(C) The Author(s) 2016. This article is published with open access at Springerlink.com

\begin{abstract}
Increasing production and disposal of coal fly ash (CFA) is a matter of serious environment concern. However, CFA contains various beneficial metals and mineral matters whose demand is increasing in the industrialized world, while natural supplies are diminishing. Therefore, recovery of these potential resources from CFA can be an alternative way to save mineral resources, as well as to reduce the environmental burden of CFA disposal. There are numerous methods developed for the recovery of beneficial products from CFA. Based on the US patents and journal literatures, the present review describes the recovery status and technologies of major elements such as $\mathrm{Al}, \mathrm{Si}, \mathrm{Fe}$ and $\mathrm{Ti}$, and trace elements such as $\mathrm{V}, \mathrm{Ga}, \mathrm{Ge}, \mathrm{Se}, \mathrm{Li}, \mathrm{Mo}, \mathrm{U}, \mathrm{Au}, \mathrm{Ag}, \mathrm{Pt}$ groups and rare earth elements (REEs) and other beneficial products such as magnetic materials, cenospheres, and unburned carbon from CFA. It also highlights the recovery efficiency and drawbacks for their extraction, and suggests future research to develop satisfactory results in terms of selective recovery and purification.
\end{abstract}

Keywords Coal fly ash · Beneficial elements · Recovery $\cdot$ Hydrometallurgical methods $\cdot$ Extraction efficiency

\section{Introduction}

Coal based thermal power plants are one of the largest sources of electricity, contributing around $39 \%$ of the total electricity generated throughout the world (Fig. 1) (US EIA 2014). This is due the fact that coal is the most abundant fossil fuel, and it is comparatively much lower priced than other fuels such as oil and natural gas. However, growing use of coal in power plants is generating

Prafulla Kumar Sahoo

prafulla.sahoo@itv.org; prafulla.iitkgp@gmail.com

1 Vale Institute of Technology, Baventura da Silva, Belem, Para 66055-090, Brazil

2 Department of Environmental Engineering, Kunsan National University, Jeonbuk 573-701, Republic of Korea

3 Prometeo, SDIC, Secretary of Higher Education, Science, Technology and Innovation (SENESCYT), Quito, Ecuador

4 Department of Mining Engineering, National Institute of Technology, Rourkela, Orissa 769008, India huge amounts "waste", known as coal fly ash (CFA), with China, the US and India being the largest producers (Heidrich et al. 2013) (Table 1). The current global annual production of CFA is approximately 750 million tonnes (Yao et al. 2015), and this is anticipated to increase in the near future. Thus, increases in the global production of CFA is a matter of serious environmental concern because of issues related not only to its disposal but also the threat to public health and potential damage to soil, agriculture and natural beauty. These problems are more critical in areas experiencing increasing land use competition. Fly ash can even reach the sub-soil and contaminate the groundwater with heavy metals (Prasad and Mondal 2009; Ramya et al. 2013). Thus, there is a pressing need of its recycling and utilization (Ilic et al. 2003; Yao et al. 2015). More efforts have been undertaken on concrete production, paving roads, mine fillings, building material production, land reclamation, soil stabilization, toxic element immobilization, and synthesis of polymers and agriculture etc. (Kruger 1997; Basu et al. 2009; Ahmaruzzaman 2010; Alam and Akhtar 2011; Loya and Rawani 2014). Taking 


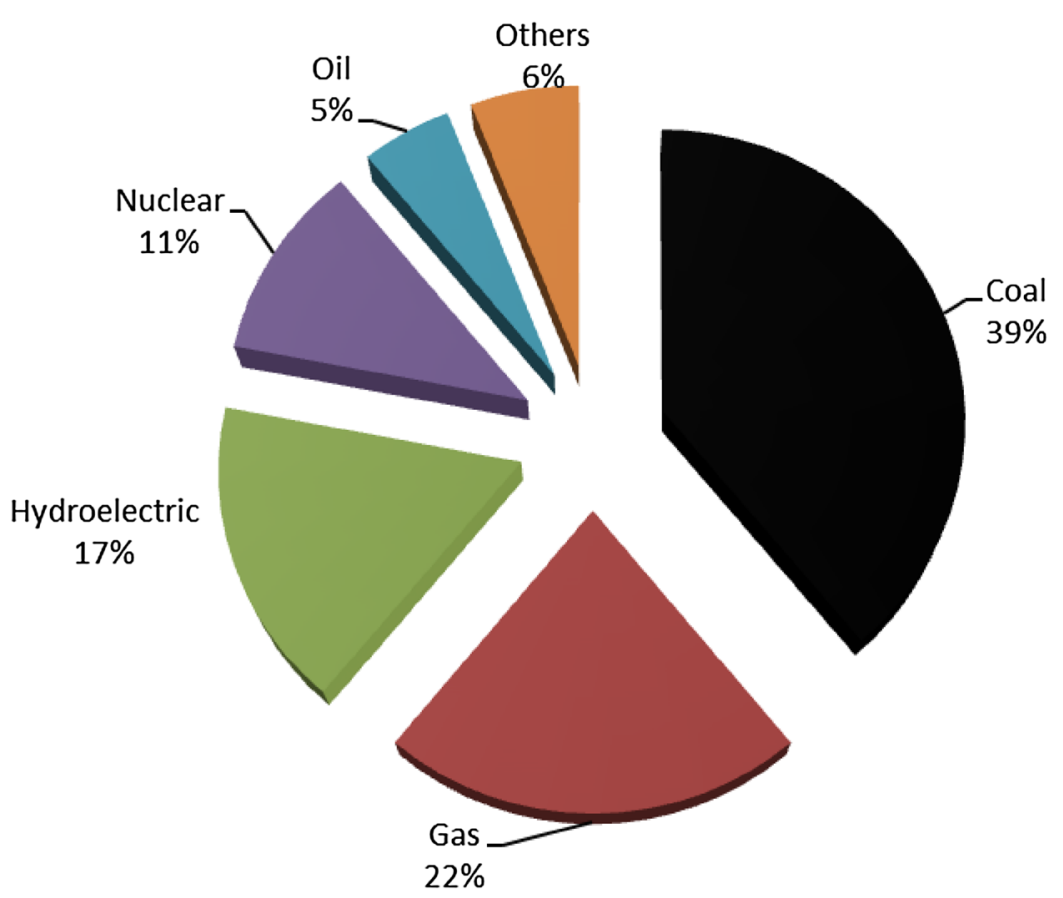

Fig. 1 World electricity production from all energy in 2014 (US EIA 2014)

Table 1 Worldwide annual production of coal fly ash (Heidrich et al. 2013)

\begin{tabular}{ll}
\hline Country & Ash production (Mt) \\
\hline China & 385 \\
USA & 118 \\
India & 105 \\
Europe & 52.6 \\
Middle East and Africa & 32.6 \\
Russian Federation & 26.6 \\
Other Asia & 16.7 \\
Australia & 13.1 \\
Japan & 11.1 \\
Canada & 6.8 \\
\hline
\end{tabular}

this into account, on average only $25 \%$ of CFA is utilized (Sommerville et al. 2013), wherein $38 \%$ for US, $47 \%$ for the EU and $15 \%$ for India (Yao et al. 2014a, b; reference therein). The rest is considered as pollutant and disposed waste. Hence, there is an urgent need for developing of its novel applications (Blissett et al. 2014).

Currently, CFA is being explored as an alternative source of valuable metals, since it mainly composes of a variety of oxygenated inorganic compounds, such as $\mathrm{SiO}_{2}$, $\mathrm{Al}_{2} \mathrm{O}_{3}, \mathrm{Fe}_{2} \mathrm{O}_{3}$ and $\mathrm{TiO}_{2}$, with smaller amounts of trace elements (Lai-shi et al. 2011; Blissett and Rowson 2012; Seredin et al. 2013; Mayfield and Lewis 2013). With diminishing metal resources as well as ever-increasing their demand, recovery of these products from CFA would be highly worthwhile and a challenging topic for current international research (Cao et al. 2008; Mayfield and Lewis 2013; Tolhurst 2015). Nevertheless, recovery of metals from CFA can reduce environmental risks associated with disposal and leaching of metals to surface and subsurface waters. There have been several reviews based on journal articles that focused on the recovery of beneficial elements and products from CFA (Jha et al. 2008; Cao et al. 2008; Meawad et al. 2010; Blissett and Rowson 2012; Yao et al. 2014a, b; Franus et al. 2015). However, the present review focused on US Patents, as well as journal articles to present an overview of the recovery status and technologies of metals and other beneficial products from CFA using several metallurgical and bio-metallurgical methods with the aim of evaluating their extraction efficiency, impact and applicability.

\section{Properties of coal fly ash}

The physico-chemical properties of CFA are highly variable depending on coal type, combustion temperature, combustion technique, air/fuel ratio, and particle size of the feed coal (Dhadse et al. 2008). The major oxides for CFA from different coal types are presented in Table 2 (Meawad et al. 2010). The principal components of all ash samples are $\mathrm{SiO}_{2}, \mathrm{Al}_{2} \mathrm{O}_{3}$, and $\mathrm{Fe}_{2} \mathrm{O}_{3}$, with varying amounts of carbon, reported as loss on ignition (LOI), $\mathrm{CaO}$, and $\mathrm{MgO}$. Higher concentrations of $\mathrm{CaO}$ and $\mathrm{MgO}$, and lower concentrations of $\mathrm{SiO}_{2}, \mathrm{Fe}_{2} \mathrm{O}_{3}$ and carbon are found in lignite 
Table 2 Major oxide concentrations in fly ash from different coal types (\%) (Meawad et al. 2010; references therein)

\begin{tabular}{llcr}
\hline Component & Bituminous & Sub-bituminous & Lignite \\
\hline $\mathrm{SiO}_{2}$ & $20-60$ & $40-60$ & $15-45$ \\
$\mathrm{Al}_{2} \mathrm{O}_{3}$ & $5-35$ & $20-30$ & $10-25$ \\
$\mathrm{FeO}_{3}$ & $10-40$ & $4-10$ & $4-15$ \\
$\mathrm{CaO}$ & 1.12 & $5-30$ & $15-40$ \\
$\mathrm{MgO}$ & $0-5$ & $1-6$ & $3-10$ \\
$\mathrm{Na}_{2} \mathrm{O}$ & $0-4$ & $0-2$ & $0-6$ \\
$\mathrm{~K}_{2} \mathrm{O}$ & $0-3$ & $0-4$ & $0-4$ \\
$\mathrm{LOI}$ & $0-15$ & $0-3$ & $0-5$ \\
\hline
\end{tabular}

and sub-bituminous CFA compared to bituminous CFA. According to the American Society of Testing Materials (ASTM C618 2000), two classes of CFA have been defined based on the coal usage. Fly ash produced from anthracite or bituminous coal is classified as class $\mathrm{F}$, while class $\mathrm{C}$ fly ash is produced from lignite or sub-bituminous coal. This classification is based on differences in contents $\mathrm{SiO}_{2}$, $\mathrm{Al}_{2} \mathrm{O}_{3}$, and $\mathrm{Fe}_{2} \mathrm{O}_{3}$, and $\mathrm{LOI}$ in the ash. In classes $\mathrm{C}$ and $\mathrm{F}$, the $\mathrm{SiO}_{2}+\mathrm{Al}_{2} \mathrm{O}_{3}+\mathrm{Fe}_{2} \mathrm{O}_{3}$ contents are $>50 \%$ and $>70 \%$ respectively, and LOI is $<6 \%$ and $<12 \%$, respectively. In addition, class $\mathrm{C}$ fly ash corresponds to high-lime (10\% up to $40 \%$ ), while Class $\mathrm{F}$ fly ash has lime concentrations $<10 \% \mathrm{CaO}$. Coal fly ash is considerably rich in trace elements (Karayigit et al. 2001; Vassilev et al. 2005; Dhadse et al. 2008). The normal range of those elements is given in Table 3 (National Research Council 2006; USEPA 1999; Meawad et al. 2010). Elements in CFA are enriched mainly based on their organic/ inorganic affinity and host mineralogy, followed by volatility (Xu et al. 2003; Vassilev et al. 2005). During fly ash gasification, the majority of mineral fractions hosting important trace elements is volatilized and then condensed on the surfaces of the fly ash (Clark and Sloss 1992; Querol et al. 1995). US Patent No. 0274886A1 (2007) illustrates the volatility classes of elements during combustion (Fig. 2). This indicated that elements such as As, B, Bi, Cd, $\mathrm{Ge}, \mathrm{Ga}, \mathrm{Mo}, \mathrm{Pb}, \mathrm{S}, \mathrm{Se}, \mathrm{Sb}, \mathrm{Sn}, \mathrm{Te}$, and Ti are classified into Class II category. These elements have tendency to more concentrate in the finer particles of the ashes during the condense-volatilization process (US Patent No. 4686031 1987; Gieré et al. 2003).

\section{Recovery of major element}

There are a number of methods have been developed for the recovery of major elements from CFA (Table 4), which are discussed below.

\subsection{Aluminum and titanium}

Aluminum ( $\mathrm{Al})$ is an industrially important metal; it is light, corrosion resistant, and malleable and is mainly used in the aircraft industry. It is also used in the production of aluminum chemicals and in refractories (Matjie et al. 2005). Titanium (Ti) is used for various purposes in industry. In particular, it has been used in the aerospace industry. Titanium oxide is used as a pigment in the paint industry. On larger-scale, Ti and titanium alloy products are used for making automotive parts (Fontana et al. 2005). Coal and coal residues such as CFA are enriched with these elements (Halina et al. 2007; Seredin 2012; Dai et al. 2012a).

Several methods have been reported for recovering $\mathrm{Al}$ from CFA. Burnet et al. (1977) introduced a chlorinating process, where the fly ash is first separated into magnetic and non-magnetic fractions. The non-magnetic fraction of CFA was mixed with carbon and chlorinated in a fixed bed. The iron remaining in this fraction was removed by lowering the temperatures between 400 and $600{ }^{\circ} \mathrm{C}$. The chlorinated aluminum fraction was recovered by increasing the temperature to $850-950{ }^{\circ} \mathrm{C}$. Following Burnet et al. (1977), Mehrotra et al. (1982a,b) studied a high-temperature chlorinating process, and found that only $25 \%$ of Al and $25 \%$ of Ti in ash could be chlorinated at temperature above $900{ }^{\circ} \mathrm{C}$. However, this process left about one-third of the iron with the nonmagnetic fraction. US Patent No. 4159310 (1979) gives a more thorough discussion of the chlorinating process for the recovery of $\mathrm{Al}$ and $\mathrm{Ti}$. In this Patent the nonmagnetic fraction of ash was chlorinated in an oxidizing atmosphere and selectively separated $\mathrm{Fe}$ from other metals. The remaining residue was then chlorinated in a reducing atmosphere in the absence of solid carbon to suppress the chlorination of $\mathrm{Si}$ and vaporized the chlorides of other metals. Aluminum and Ti were selectively separated and recovered by condensation from the vapors. Overall, this method recovered $70 \%-80 \% \mathrm{Al}$ and $80 \%$ Ti. However, this method can become very expensive if the chlorination of unwanted metals is not suppressed.

Another method for the recovery of $\mathrm{Al}$ and $\mathrm{Ti}$ involves leaching CFA by acid/alkali leaching followed by precipitation, solvent extraction, or re-crystallization (Matjie et al. 2005; Halina et al. 2007; Li et al. 2011). US Patent No. 4243640 (1981) investigated a process for the recovery of $\mathrm{Al}$ from CFA where the ash was subjected to a magnetic separation and subsequently leaching was carried out on the non-magnetic fraction using nitric acid (strength about $30 \%-56 \%$ ). The leachate was then evaporated and calcinated at $1000{ }^{\circ} \mathrm{C}$ for the recovery of Al. The calcinated product contained $90 \%$ alumina along with other impurities like Fe oxides. US Patent No. 4567026 (1986) reported another acid leaching method for the recovery of $\mathrm{Al}$ and $\mathrm{Ti}$ 


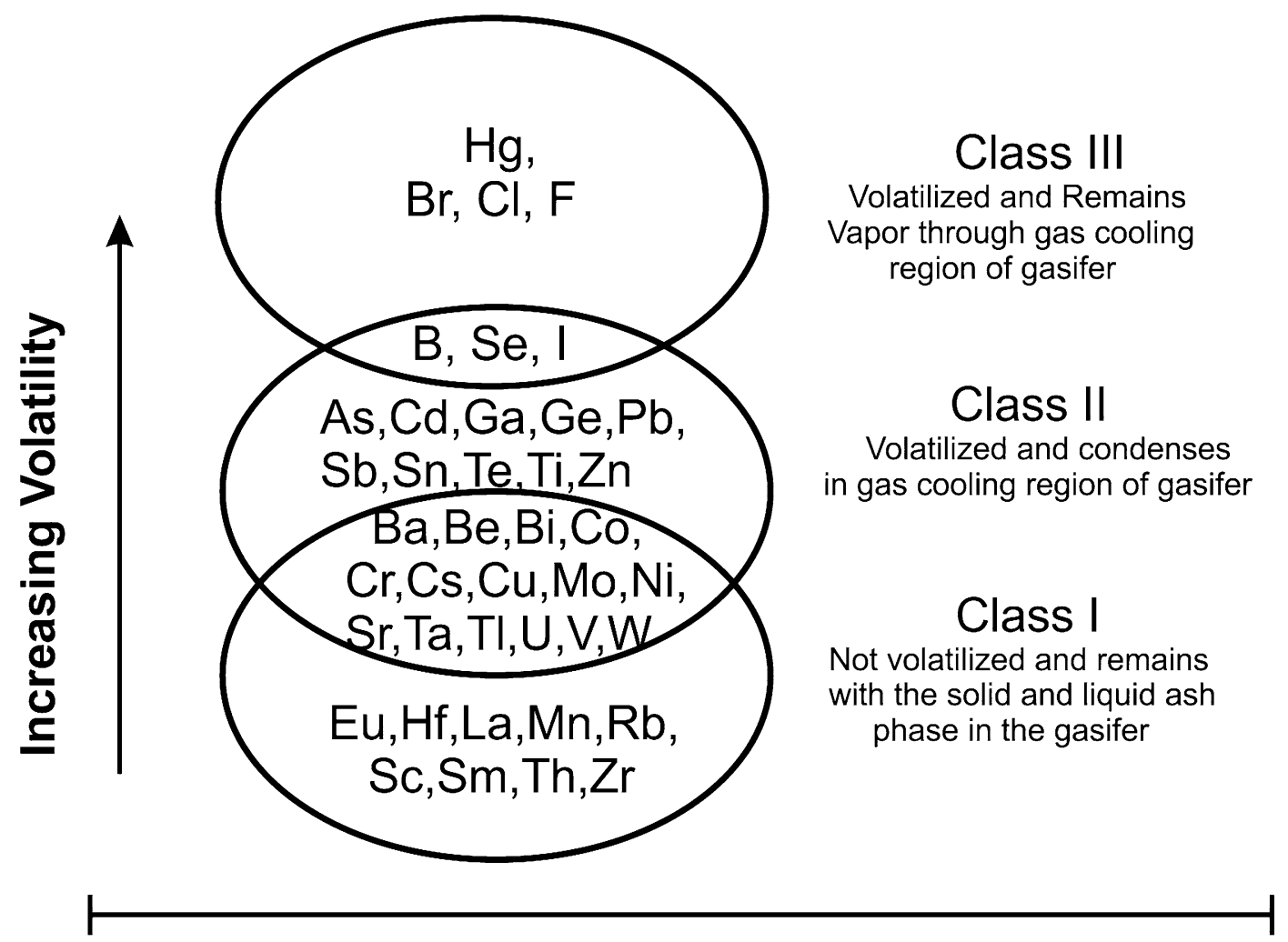

Fig. 2 Relative volatility of trace elements in coal gasification systems (US Patent 0274886A1 2007)

Table 3 Trace element concentrations in fly ash $(\mathrm{mg} / \mathrm{kg}$ ) (National Research Council 2006; USEPA 1999; Meawad et al. 2010)

\begin{tabular}{llc}
\hline Element & Median & Range \\
\hline $\mathrm{As}$ & 43.4 & $0.0003-391$ \\
$\mathrm{Ba}$ & 806.5 & $0.02-10,850$ \\
$\mathrm{Be}$ & 5 & $0.2-2105$ \\
$\mathrm{~B}$ & 311 & $2.98-2050$ \\
$\mathrm{Cd}$ & 3.4 & $0.01-79$ \\
$\mathrm{Cr}$ & 136 & $3.6-437$ \\
$\mathrm{Co}$ & 35.9 & $4.9-79$ \\
$\mathrm{Cu}$ & 112 & $0.2-655$ \\
$\mathrm{~F}$ & 29 & $0.04-320$ \\
$\mathrm{~Pb}$ & 56.8 & $0.02-273$ \\
$\mathrm{Mn}$ & 250 & $24.5-750$ \\
$\mathrm{Hg}$ & 0.1 & $0.013-49.5$ \\
$\mathrm{Ni}$ & 77.7 & $0.1-1270$ \\
$\mathrm{Se}$ & 7.7 & $0.0003-46.5$ \\
$\mathrm{Sb}$ & 4.6 & $0.2-205$ \\
$\mathrm{Ag}$ & 3.2 & $0.01-49.5$ \\
$\mathrm{Sr}$ & 775 & $30-3885$ \\
$\mathrm{Tl}$ & 9 & $0.15-85$ \\
$\mathrm{~V}$ & 252 & $43.5-5015$ \\
$\mathrm{Zn}$ & 148 & $0.28-2200$ \\
\hline & &
\end{tabular}

from CFA. The process involved separation of magnetic fractions from the ash, followed by leaching the nonmagnetic fraction with sulfuric acid, precipitating and removing $\mathrm{Ti}$ and $\mathrm{Fe}$ oxides from the leach solution by adding a strong base $(\mathrm{NaOH})$, and precipitating and removing $\mathrm{Al}$ by contacting the reclaiming solution with $\mathrm{CO}_{2}$. The precipitated aluminium hydroxide is calcinated to get aluminum oxide. However, direct sulfuric acid leaching yielded a low aluminum extraction (Matjie et al. 2005). Nayak and Panda (2010) also showed that direct sulphuric acid leaching at low concentration did not yield high aluminum recovery.

In contrast, CFA was treated pelletized with lime and calcinated, leaching with sulfuric acid that yielded better recovery. US Patent No. 4254088 (1981) discusses a process where the CFA was sintered with a mixture of $\mathrm{NaCl}$ and $\mathrm{Na}_{2} \mathrm{CO}_{3}$ at a temperature $700-900{ }^{\circ} \mathrm{C}$. After sintering, $90 \%$ of the aluminum CFA was in the acid soluble fraction. Recently, Matjie et al. (2005) discussed this calcinated technique at high temperature to decompose mullite phases, and then the calcinated CFA was leached in sulfuric acid to produce a solution containing $\mathrm{Fe}, \mathrm{Al}$ and $\mathrm{Ti}$ species. The selective recovery of $\mathrm{Al}$ and $\mathrm{Ti}$ was carried out using various extraction methods, solvent extraction was more efficient than others and recovered $99.4 \%$ of 
Table 4 Recovery of major and trace elements, their extraction methods and recovery efficiency from coal fly ash

\begin{tabular}{|c|c|c|c|c|}
\hline References & Element & Method & Chemical reagent/others & Recovery efficiency \\
\hline Burnet et al. (1977) & $\mathrm{Al}$ & High-temperature chlorination & Carbon, chlorine & Not known \\
\hline Mehrotra $(1982 \mathrm{a}, \mathrm{b})$ & $\mathrm{Al}, \mathrm{Ti}$ & High-temperature chlorination & $\begin{array}{l}\text { Carbon, carbon monoxide, } \\
\text { chlorine }\end{array}$ & $25 \% \mathrm{Al}, 25 \%$ of $\mathrm{Ti}$ \\
\hline $\begin{array}{l}\text { US Pat. No. } 4159310 \\
\text { (1979) }\end{array}$ & $\mathrm{Al}, \mathrm{Ti}$ & High-temperature chlorination & $\begin{array}{l}\text { Carbon monoxide, chlorine, } \\
\mathrm{H}_{2} \mathrm{SO}_{4}\end{array}$ & $\begin{array}{l}70 \%-80 \% \mathrm{Al}, 80 \% \\
\mathrm{Ti}\end{array}$ \\
\hline $\begin{array}{l}\text { US Pat. No. } 4243640 \\
\text { (1981) }\end{array}$ & $\mathrm{Al}$ & $\begin{array}{l}\text { Magnetic separation, acid } \\
\text { leaching, calcination }\end{array}$ & $\mathrm{HNO}_{3}$ & Up to $90 \% \mathrm{Al}$ \\
\hline $\begin{array}{l}\text { US Patent No. } 4567026 \\
\text { (1986) }\end{array}$ & $\mathrm{Al}, \mathrm{Ti}$ & $\begin{array}{l}\text { Magnetic separation, leaching, } \\
\text { calcination }\end{array}$ & $\mathrm{H}_{2} \mathrm{SO}_{4}, \mathrm{NAOH}, \mathrm{CO}_{2}$ & Not known \\
\hline $\begin{array}{l}\text { US Patent No. } 4254088 \\
\text { (1981) }\end{array}$ & $\mathrm{Al}, \mathrm{Ti}$ & Salt-soda sintering, leaching & $\mathrm{NaCl}, \mathrm{Na}_{2} \mathrm{CO}_{3}, \mathrm{HNO}_{3} / \mathrm{H}_{2} \mathrm{SO}_{4}$ & $90 \% \mathrm{Al}$ \\
\hline Matjie et al. (2005) & $\mathrm{Al}, \mathrm{Ti}$ & $\begin{array}{l}\text { Calcination, leaching, solvent } \\
\text { extraction }\end{array}$ & $\mathrm{CaO}, \mathrm{H}_{2} \mathrm{SO}_{4}$ & $\begin{array}{l}99.4 \% \mathrm{Al}_{2} \mathrm{O}_{3}, 97 \% \\
\mathrm{TiO}_{2}\end{array}$ \\
\hline $\begin{array}{l}\text { US Pat. No. } 4539187 \\
\text { (1985) }\end{array}$ & $\mathrm{Al}, \mathrm{Ti}$ & Acid leaching & Fluorosilicic acid, HF & Not known \\
\hline Wu et al. (2012) & $\mathrm{Al}$ & Pressure acid-leaching & $\mathrm{H}_{2} \mathrm{SO}_{4}$ & $82.4 \% \mathrm{Al}$ \\
\hline $\begin{array}{l}\text { US Pat. No. } 4130627 \\
\text { (1978) }\end{array}$ & $\mathrm{Al}, \mathrm{Fe}$ & Alkaline leaching, electrolysis & $\mathrm{NaOH}, \mathrm{HCl} / \mathrm{HF}$ & $65 \% \mathrm{Fe}, 89 \% \mathrm{Al}$ \\
\hline Padil and Sohn (1985) & $\mathrm{Al}$ & Lime-soda sintering & $\mathrm{CaCO}_{3}, \mathrm{NaCO}_{3}$ & $50 \%-60 \%$ alumina \\
\hline Lu et al. (2003) & $\mathrm{Al}$ & Lime-soda sintering & Limestone, $\mathrm{NaHCO}_{3}$ & $70 \%$ alumina \\
\hline Bai et al. (2010) & $\mathrm{Al}$ & Lime-soda sintering & Lime, $\mathrm{NaCO}_{3}, \mathrm{NaOH}$ & $90 \%$ alumina \\
\hline $\begin{array}{l}\text { US Pat No. 4397822A } \\
\text { (1983) }\end{array}$ & & Lime-soda sintering & $\mathrm{CaCO}_{3}, \mathrm{NaCO}_{3}$, Sulfur, carbon & $90 \%$ alumina \\
\hline $\begin{array}{l}\text { US Pat No. 0119426A1 } \\
\text { (2010) }\end{array}$ & $\mathrm{Si}, \mathrm{Al}$ & Leaching, calcination & $\mathrm{NaOH}, \mathrm{CO}_{2}, \mathrm{CaO}, \mathrm{H}_{2} \mathrm{SO}_{4}$ & Not known \\
\hline $\begin{array}{l}\text { US Pat No. 7871583B2 } \\
\text { (2011) }\end{array}$ & $\mathrm{Si}, \mathrm{Al}$ & Leaching, calcination & $\mathrm{NaOH}, \mathrm{CO}_{2}, \mathrm{CaO}, \mathrm{H}_{2} \mathrm{SO}_{4}$ & Not known \\
\hline US Pat No. 5231018 (1993) & $\mathrm{Al}, \mathrm{Ti}$ & Bioleaching & $\begin{array}{l}\mathrm{C} \text { and } \mathrm{N} \text { source, } \mathrm{GIN}-1 \text {, growth } \\
\text { medium }\end{array}$ & Not known \\
\hline US Pat No. 5278069 (1994) & $\mathrm{Al}, \mathrm{Ti}$ & Bioleaching, acid precipitation & Thiobacillus thiooxidans & Not known \\
\hline $\begin{array}{l}\text { US. Pat No. } 4539187 \\
\text { (1985) }\end{array}$ & $\mathrm{Si}$ & Acid leaching & $\mathrm{SiF}_{4}, \mathrm{HF}$ & Not known \\
\hline $\begin{array}{l}\text { US Pat. No 0287827A1 } \\
\text { (2010) }\end{array}$ & $\mathrm{Si}$ & Acid leaching & HF, coal, $\mathrm{S}$ & Not known \\
\hline $\begin{array}{l}\text { US Pat. No. 0119426A1 } \\
\text { (2010) }\end{array}$ & $\mathrm{Si}$ & Alkaline leaching, carbonation & $\mathrm{NaOH}, \mathrm{H}_{2} \mathrm{SO}_{4}, \mathrm{CaO}, \mathrm{CO}_{2}$ & $>98.5 \% \mathrm{SiO}_{2}$ (purity) \\
\hline $\begin{array}{l}\text { US Pat. No. 7871583B2 } \\
\text { (2011) }\end{array}$ & $\mathrm{Si}$ & Alkaline leaching, carbonation & $\mathrm{NaOH}, \mathrm{H}_{2} \mathrm{SO}_{4}, \mathrm{CaO}, \mathrm{CO}_{2}$ & $>98.5 \% \mathrm{SiO}_{2}$ (purity) \\
\hline US Pat. No 4814150 (1989) & $\mathrm{V}$ & Leaching, precipitation & $\mathrm{NaOH}, \mathrm{H}_{2} \mathrm{SO}_{4}$, ammonium salt & $80 \%-90 \%$ \\
\hline $\begin{array}{l}\text { US Pat. No. } 4966761 \\
\text { (1990) }\end{array}$ & $\mathrm{V}$ & Leaching, solvent extraction & $\begin{array}{l}\mathrm{NaOH} \text {, resin, } \mathrm{HCl}, \mathrm{NH} 4 \mathrm{Cl}, \\
\text { quaternary amine }\end{array}$ & Up to $93.4 \% \mathrm{~V}$ \\
\hline $\begin{array}{l}\text { US Pat. No. 7498007B2 } \\
\text { (2009) }\end{array}$ & $\mathrm{V}$ & Acidic leaching & $\begin{array}{l}\text { Calcium hydroxide, quick lime, } \\
\text { acid }\end{array}$ & $>98 \%$ \\
\hline Xiang-yang et al. (2010) & $\mathrm{V}$ & Acid leaching & $\mathrm{H}_{2} \mathrm{SO}_{4}$ & $95 \%$ \\
\hline Vitolo et al. (2000) & $\mathrm{V}$ & Combustion, acid leaching & $\mathrm{H}_{2} \mathrm{SO}_{4}, \mathrm{NaClO}_{3}$ & $83 \%$ \\
\hline $\begin{array}{l}\text { US Pat. No. 6652819B2 } \\
\text { (2003) }\end{array}$ & $\mathrm{V}$ & Combustion, acid leaching & $\mathrm{H}_{2} \mathrm{SO}_{4}$ & Not known \\
\hline US Pat No. 4475993 (1984) & $\mathrm{Ga}$, others & Alkali halite melt, electrolysis & Aluminium trichloride & $69 \%$ of $\mathrm{Ga}$ \\
\hline US Pat No. 4643110 (1987) & $\mathrm{Ga}, \mathrm{Ge}$ & Sublimation & & Not known \\
\hline US Pat No. 4678647 (1986) & $\mathrm{Ga}, \mathrm{Ge}$ & Sublimation & & Up to $90 \% \mathrm{Ga}$ \\
\hline US Pat No. 4757772 (1988) & $\mathrm{Ge}, \mathrm{Ga}$ & Sublimation & & Not known \\
\hline US Pat No. 4678647 (1986) & $\mathrm{Ge}, \mathrm{Ga}$ & Sublimation & & Up to $90 \% \mathrm{Ga}$ \\
\hline
\end{tabular}


Table 4 continued

\begin{tabular}{|c|c|c|c|c|}
\hline References & Element & Method & Chemical reagent/others & Recovery efficiency \\
\hline Arroyo et al. (2014) & $\mathrm{Ge}, \mathrm{Ga}$ & $\begin{array}{l}\text { Acid, alkaline, complexant } \\
\text { leaching }\end{array}$ & Oxalic acid, sulfuric acid & $\begin{array}{l}\text { Up to } 90 \% \mathrm{Ge} \text {; up to } \\
82 \% \mathrm{Ga}\end{array}$ \\
\hline Gutiérrez et al. (1997) & $\mathrm{Ga}$ & Acid leaching & $\mathrm{HCl}$, Amberlite LA-2 & $83 \%$ of $\mathrm{Ga}$ \\
\hline Fang and Gesser (1996) & $\mathrm{Ga}$ & Acid leaching, flotation & $\mathrm{HCl}$ & Up to $80 \%$ of $\mathrm{Ga}$ \\
\hline Arroyo et al. (2009) & $\mathrm{Ge}$ & $\begin{array}{l}\text { Water leaching, solvent } \\
\text { extraction }\end{array}$ & Water, catechol, $\mathrm{NaOH}$ & $95 \% \mathrm{Ge}$ \\
\hline Font et al. (2005) & $\mathrm{Ge}$ & Water leaching & & $86 \%$ of $\mathrm{Ge}$ \\
\hline Mok et al. (1984) & Mo & $\begin{array}{l}\text { Acid digestion, solvent } \\
\text { extraction }\end{array}$ & $\mathrm{HCl}, \mathrm{HNO}_{3}$, dithiocarbamate & Not known \\
\hline Ogata et al. (2011) & Mo & Acid/alkaline leaching & $\mathrm{HCl}, \mathrm{NaOH}$, gibbsite & $90 \%$ of Mo \\
\hline $\begin{array}{l}\text { US Pat. No. } 3857920 \\
\text { (1974) }\end{array}$ & $\mathrm{Li}$ & Leaching & Water, $\mathrm{CO}_{2}$ & $\begin{array}{c}80 \%-90 \% \text { of } \\
\mathrm{Li}_{2} \mathrm{CO}_{3}\end{array}$ \\
\hline Wang et al. (2007) & $\mathrm{Se}$ & Leaching & $\mathrm{HNO}_{3}, \mathrm{NaOH}$ & $55 \%-69 \%$ at $\mathrm{pH} 12$ \\
\hline Sparton Res Inc. (2007) & $\mathrm{U}$ & Acid leaching, ion-exchange & $\mathrm{H}_{2} \mathrm{SO}_{4}$, resin & Not known \\
\hline Maslov et al. (2010) & $\mathrm{U}, \mathrm{Ra}$ & Acid leaching & $\mathrm{HNO}_{3}, \mathrm{HF}$ & U (99 \%), Ra (97\%) \\
\hline $\begin{array}{l}\text { Us Pat No. 6827837B2 } \\
\text { (2004) }\end{array}$ & $\mathrm{Au}, \mathrm{Pt}$ group & $\begin{array}{l}\text { Combustion, acid digestion, } \\
\text { precipitation }\end{array}$ & $\mathrm{HNO}_{3}, \mathrm{HCl}$ & Not known \\
\hline $\begin{array}{l}\text { US Pat No. 0056548A1 } \\
\text { (2005) }\end{array}$ & $\mathrm{Au}, \mathrm{Pt}$ group & $\begin{array}{l}\text { Combustion, acid digestion, } \\
\text { precipitation }\end{array}$ & $\mathrm{HNO}_{3}, \mathrm{HCl}$ & Not known \\
\hline US Pat No. 4649031 (1987) & REEs & $\begin{array}{l}\text { Sieving, aqueous alkali/acid } \\
\text { digestion }\end{array}$ & $\mathrm{Na}_{2} \mathrm{CO}_{3}, \mathrm{HCl}, \mathrm{HNO}_{3}$ & Not known \\
\hline $\begin{array}{l}\text { US Pat No. 0287653A1 } \\
\text { (2013) }\end{array}$ & REEs & Acid leaching, Ion-exchange & $\begin{array}{l}\mathrm{HNO}_{3} \text {, tributyl phosphate, } \\
\text { kerosene }\end{array}$ & Not known \\
\hline $\begin{array}{l}\text { US Pat No. 8968688B2 } \\
\text { (2015) }\end{array}$ & REEs & Acid leaching, Ion-exchange & $\begin{array}{l}\mathrm{HNO}_{3} \text {, tributyl phosphate, } \\
\text { kerosene }\end{array}$ & Not known \\
\hline Narukawa et al. (2007) & $\mathrm{Cr}$ & Alkaline leaching & $\mathrm{NaOH}$ & Not known \\
\hline Huang et al. (2011) & $\mathrm{Pb}, \mathrm{Zn}$ & Alkaline leaching & $\mathrm{NH} 4 \mathrm{OH} / \mathrm{NaOH}$ & Not known \\
\hline Okada et al. (2007) & $\mathrm{Zn}, \mathrm{Pb}$ & Acid leaching & $\mathrm{CH}_{3} \mathrm{COOH}$ & $97 \% \mathrm{Zn}, 98 \% \mathrm{~Pb}$ \\
\hline Hong et al. (2000) & $\mathrm{Cr}, \mathrm{Cu}, \mathrm{Pb}, \mathrm{Zn}$ & Leaching & Chelating agents (EDTA) & $\begin{array}{l}20 \%-50 \% \mathrm{Cr}, 60 \%- \\
95 \% \mathrm{Cu} \\
60 \%-100 \% \mathrm{~Pb} \\
50 \%-100 \% \mathrm{Zn}\end{array}$ \\
\hline $\begin{array}{l}\text { US Pat. No. } 5278069 \\
\text { (1994) }\end{array}$ & Co, others & Bioextraction & Thiobacillus thiooxidans & Not known \\
\hline
\end{tabular}

$\mathrm{Al}_{2} \mathrm{O}_{3}$ and $97 \%$ of $\mathrm{TiO}_{2}$. US Patent No. 4539187 (1985) also used an acid treatment where CFA was reacted with concentrated fluorosilicic acid and hydrogen fluoride at high temperature to form aqueous silicon fluoride vapor and fluoride and fluorosilicate of $\mathrm{Al}$ and Fe. Separated the $\mathrm{Al}$ and $\mathrm{Fe}$ bearing fluorides and fluorosilicate from aqueous silicon vapor, hydrolyzed and then recovered the substantial amount of pure $\mathrm{Fe}$ and $\mathrm{Al}$ following electroplating process. Recently, Wu et al. (2012) demonstrated pressure acid-leaching method, wherein the high extraction $(82.4 \%)$ of $\mathrm{Al}$ was obtained by diminishing CFA size $(74 \mu \mathrm{m})$ and increasing acid concentrations (50\%). However in this method, the non-target metals readily leached into the acid, resulting in impurities. In addition, acid leaching had limited application due to its highly corrosive nature, besides this process required high cost, acid resistant equipment, and air-tight processing to protect the work environment.

Recovery of alumina by alkaline leaching is less problematic than techniques using acid leaching. US Patent No. 4130627 (1978) describes the alkaline leaching method where in the process takes place in an aqueous alkali solution of approximately $\mathrm{pH} 13$, using $\mathrm{NaOH}$, to form an aqueous CFA blend. The blend was agitated on a hotplate at temperatures of about $90{ }^{\circ} \mathrm{C}$, and filtered to recover an alkaline solid. The filtrate was then contacted with hydrochloric or hydrofluoric acid to form soluble salts of various metals. Iron and aluminum were then selectively 
precipitated and recovered. This process recovered $65 \%$ by weight of $\mathrm{Fe}$ and about $89 \%$ of Al. However, this process has some disadvantages, such as being complex, time consuming, requiring larger quantities of processing materials, and high facility costs. This problem can be dealt with lime-soda sinter process, where a mixture of CFA, calcium carbonate, and sodium carbonate was sintered at high temperature to form a soluble sodium and calcium aluminate (Padil and Sohn 1985). Lu et al. (2003) reported this process where the CFA was mixed with limestone, sintered at $1260{ }^{\circ} \mathrm{C}$, and then dissolved in sodium carbonate solution at $80{ }^{\circ} \mathrm{C}$. This process obtained $99.9 \%$ purity of alumina, and its recovery efficiency was $70 \%$. Recently, Bai et al. (2010) also used a lime-soda sintering method for the recovery of aluminum from an alkali desilicated CFA. The final Al extraction efficiency was $90 \%$. This process extracted $\mathrm{Al}$ from nearly $88 \%-92 \%$ at temperatures below $85{ }^{\circ} \mathrm{C}$, while $\mathrm{Al}$ was not fully released from the sintered ash when the temperature was greater than $85{ }^{\circ} \mathrm{C}$. US Patent No. 4397822A (1983) demonstrated an improvement method which added a small amount of sulfur and carbon to the lime-CFA sinter mixture before sintering to lower the optimum sinter temperature. This method recovered almost $90 \%$ of alumina from CFA, and the results indicate that the addition of a combination of $\mathrm{S}$ and $\mathrm{C}$, either elementally or as coal refuse, produces a higher recovery of alumina from CFA and at lower sintering temperatures, resulting in an energy savings. Recently, two US Patent Nos. 0119426A1 (2010) and 7871583B2 (2011) released a method for the recovery of alumina from high Si containing CFA, where CFA is leached with highly concentrated $\mathrm{NaOH}(>40 \%)$. Silica is first removed from the CFA in the form of $\mathrm{Na}_{2} \mathrm{SiO}_{3}$, followed by separation of the residues having $\mathrm{Al}: \mathrm{Si} \geq 2$. Subsequently the product was calcinated at $900-1100{ }^{\circ} \mathrm{C}$ to get pure alumina.

Besides acid/alkaline leaching, bioleaching also is used for the recovery of metals from CFA. This is discussed by in US Patent No. 5231018 (1993), where the CFA is suspended in an aqueous saline solution having $\mathrm{pH}$ ranging from 5 to 8 , and then forming a reactive mixture by adding a pure culture a gram-positive bacteria (GIN-1), genus Rhodococcus. The mixture is then incubated for a period of time sufficient for the formation of microorganism cells/ metal oxide adsorbate agglomerates, which separate from the reaction mixture. In this process, incubation reaction time was adjusted to selectively recover $\mathrm{TiO}_{2}$ and $\mathrm{Al}_{2} \mathrm{O}_{3}$ from CFA. In another biochemical study, US Patent No. 5278069 (1994) used Thiobacilus thiooxidans strain in an acidic media for the recovery of metals from CFA. The metals were selectively recovered by precipitating the solution by adjusting the $\mathrm{pH}$. Aluminum was mostly precipitated at $\mathrm{pH} 3.1-4.7$, while $\mathrm{Ti}$ was precipitated at $\mathrm{pH}$
1.5-3.1. These results indicate that bioleaching is one of the most cost-effective methods for the removal of metals from CFA; however, the percentage of metal recovery and their purity have not been reported.

\subsection{Silica}

Silica is used for various purposes, such as semi-conductors, soda-lime glass, high temperature thermal protection fabrics, glasses (including borosilicate glass and lead glass), and contact lenses and medical devices (Lukkassen and Meidell 2007). Coal fly ash is enriched with silica.

Several methods have been developed for the recovery of silica such as acid or alkali leaching, followed by separation and purification using different techniques. US Patent No. 4539187 (1985) describes a method where CFA is reacted with fluorosilicic acid and hydrogen fluoride at a high temperature to form fluorides of $\mathrm{Fe}, \mathrm{Al}$ and $\mathrm{Si}$. The fluoride mixture is distilled, separating the aqueous and gaseous silicon fluoride from the mixtures, hydrolyzing the silicon fluorides vapor, and recovering silicon dioxide in high purity form. Recently, US Patent No. 0287827A1 (2010) released a method where a mixture of coal and CFA is reacted with hydrogen fluoride in water to produce a liquid stream containing silicon fluoride and metal fluorides, and a solid stream containing unreacted coal and $\mathrm{S}$ compounds. Sulfur compounds are reacted with metallic nitrates dissolved in the water, which separated the aqueous solution of nitrate, $\mathrm{S}$ and metallic ions from the solid coal, and the solid coal is then washed with water. Subsequently, silicon fluoride and metal fluorides are contacted with metallic nitrates in an aqueous mixture to form solid silicon dioxide, and solid silicon dioxide is separated from the aqueous mixture. This process has recovered high purity silica from CFA. However, acid leaching is not always appropriate because it needs better acid resistant and airtight processing equipment and it causes environmental pollution. This problem can be solved by using alkaline leaching methods. US Patent Nos. 0119426A1 (2010) and 7871583B2 (2011) released an alkaline leaching method for the recovery of silica from CFA, where $\mathrm{Si}$ is leached using $\mathrm{NaOH}$ in the form of $\mathrm{Na}_{2} \mathrm{SiO}_{3}$ solution. The solution is vaporized to obtain $\mathrm{Na}_{2} \mathrm{SiO}_{3}$, and pure silica ( $>98.5 \%$ ) is produced by carbonation.

\section{Recovery of trace elements}

There are a number of methods have been developed for the recovery of trace elements from CFA (Table 4), which are discussed below. 


\subsection{Vanadium}

Vanadium (V) is mainly used in ferrous and non-ferrous alloys due to its tensile strength, hardness, and fatigue resistance (Moskalyk and Alfantazi 2003; Navarro et al., 2007). In addition, $\mathrm{V}$ is used in vanadium redox batteries. Although, $\mathrm{V}$ is extracted from various sources, V-enriched coal and carbonaceous residues such as CFA are one of the most important sources (Dai et al. 2015a).

Numerous methods have been used to extract $\mathrm{V}$ from carbonaceous residues. The most common method is wet treatment where the residue is subjected to multi-stage leaching, followed by precipitation via $\mathrm{pH}$ adjustment and oxidation/reduction (Europian Patent No. JP-A-H08325651 1996; H10-251025 1998). US Patent No. 4814150 (1989) created a process where the combustion residue is reacted with sodium hydroxide in the presence of an oxidizer, dried at $100-250{ }^{\circ} \mathrm{C}$, and leached with water to selectively extract $\mathrm{V}$. Vanadium is precipitated from the alkaline extract by adding $\mathrm{H}_{2} \mathrm{SO}_{4}$ (up to $\mathrm{pH}$ 2) and an ammonium salt. The precipitated ammonium polyvanadate is calcinated to get vanadium pentoxide, which yields $80 \%-90 \%$ of V. US Patent No. 4966761 (1990) discusses a process in which CFA is mixed with water to prepare a slurry, carbon is skimmed off followed by alkaline pressure leaching and solvent extraction for the recovery of $\mathrm{V}$ (up to $93.4 \%$ ). US Patent No. 7498007B2 (2009) uses an acid solution to recover $\mathrm{V}$. The extraction is carried out by precipitating vanadium pentoxide as a result of increasing $\mathrm{pH}$ by adding calcium hydroxide, quick lime, or calcium carbonate to the acid solution. After V is precipitated, the solid is separated by filtration or centrifugation. The percentage of $\mathrm{V}$ recovery from the acidic solution was $\geq 98 \%$. Recently, Xiang-yang et al. (2010) also described an acid leaching process using large volumes of sulfuric acid, extracting V up to $95.8 \%$ from the leachate; however, no purification of $\mathrm{V}$ was attempted. Wet treatment techniques using acid/alkali leaching still have problems since they need a relatively large amount of expensive reagents, and they deal with complicated, troublesome repetition of steps, including conversion of solid CFA to a solution, isolating $\mathrm{V}$ from other metals and reconversion of $\mathrm{V}$ the solution into a solid. In addition, this technique may be unsuitable for CFA samples containing a high carbonaceous fraction and a low concentration of $\mathrm{V}$ because leaching V may not be efficient. To cope with this problem, dry treatment techniques have been developed (US Patent Nos. 4420464 1983, 4816236 1989). In these methods, the carbon is removed by combusting the V-containing residue at a controlled temperature, and then the residue is leached with a strong alkali/acid to recover the vanadium. Vitolo et al. (2000) used this method for the recovery of $\mathrm{V}$ from a fly ash at temperatures of $650-1150{ }^{\circ} \mathrm{C}$, followed by an acid leaching and oxidative precipitation of vanadium pentoxide. Overall, this process yielded $83 \%$ V. US Patent No. 6652819B2 (2003) also employed this method for the recovery of $\mathrm{V}$ from carbonaceous residues. The method involves a preliminary combustion of the residue at temperatures of $500-690{ }^{\circ} \mathrm{C}$, followed by leaching with $\mathrm{H}_{2} \mathrm{SO}_{4}$ at a $\mathrm{pH}$ range of $1.5-4$, and selective precipitation $\mathrm{V}$ by adjusting the $\mathrm{pH}$ in the range of 4.5-7.5, and separating the $\mathrm{V}$ ion as a tetravalent vanadium compound.

\subsection{Gallium and germanium}

Gallium $(\mathrm{Ga})$ is used for the manufacture of high technology optical devices such as semiconductors, DVD's, laser diodes, and other electronic devices (Moskaly 2004). Germanium (Ge) is used in the manufacture of photovoltaic cells, fiber optics and as a catalyst for polyethylene terephthalate production (Butterman and Jogerson 2005). Germanium and gallium in the Earth's crust are mainly associated with $\mathrm{Zn}$ and its mineral phases. Thus, they are typically recovered from by-products of $\mathrm{Zn}$ mineral processing. Germanium and $\mathrm{Ga}$ are also enriched in coals (Gluskoter et al. 1977; Harvey et al. 1983; Dai et al. 2012a, b; Seredin 2012; Dai et al. 2014b; Qin et al. 2015a, b; Dai et al. 2015b). Thus, coal fly ash is a promising alternative resource of those elements (Fang and Gesser 1996; Zhang et al. 1999; Arroyo et al. 2014; Dai et al. 2014a, b). After combustion in a coal burning power plant, both elements condense from the vapor phase onto the surface of the CFA, thus are enriched in CFA relative to the feed coal (Font et al. 2005; Querol et al. 1995).

Several techniques have been developed for the recovery of Ge and Ga from CFA. Alkali halite melt is one of the methods, and is discussed in US Patent No. 4475993 (1984). In this method, the CFA is reacted with aluminium trichloride to form a soluble compound of trace metals in the melt. Gallium was recovered from the melt by electrolysis. However, this process is uneconomical and recovered a moderate percentage (69\%) of Ga. Another method of $\mathrm{Ga}$ and $\mathrm{Ge}$ extraction is sublimation, which is discussed in several US Patents (Nos. 4757772 1988, 47577701988 , and 4643110 1987). The steps include heating the CFA in an oxidizing atmosphere to vaporize the $\mathrm{Ge}$ and $\mathrm{Ga}$, then treating the oxides in a reducing atmosphere to reduce oxides to suboxides, which subsequently precipitate on the surface of sand particles, and recovery of the products from the sand particles using a cold liquid solution. This method has problems involving other volatile compounds such as As and S. To cope with this problem, US Patent No. 4678647 (1986) introduced a method where CFA is pelletized and treated in the presence of an oxidizing gas at a temperature of about $900{ }^{\circ} \mathrm{C}$. This treatment removes As and S from the CFA, so that they 
will not remain in the concentrated $\mathrm{Ga}$ and Ge fractions. Then, the oxides are treated in the presence of a reducing gas at the same temperature range to reduce the oxides to suboxides. Recover of Ga suboxides is done by condensation at a lower temperature (nearly $700-800{ }^{\circ} \mathrm{C}$ ) and dissolving the condensed material using an acidic solution. The recovery rate of Ga for this method is up to $90 \%$. This method can be more economical and more efficient than the alkali halite method.

Other techniques for the recovery of Ga and Ge include using water/acid/alkali leaching of CFA, followed by separation/purification by using precipitation, distillation, ion flotation, adsorption into activated carbon, and solvent extraction (Meawad et al. 2010). Arroyo (2014) optimized Ge and Ga recovery from CFA using different extractants in a wide range of extraction conditions (acid, alkaline, complexant, reducing and oxidizing). High extraction yields of Ge (up to $90 \%$ ) and $\mathrm{Ga}$ (up to $82 \%$ ) were made using weak oxalic acid and sulfuric acid solution, respectively within 1-2 h extraction period. Gutiérrez et al. (1997) discuss the recovery of $\mathrm{Ga}$ from CFA by $6 \mathrm{M}$ hydrochloric acid in contact with Amberlite LA-2. Iron is precipitated with sodium hydroxide, while $83 \%$ of Ga remains in solution, which is extracted selectively with LIX 54. Fang and Gesser (1996) studied the recovery of Ga from CFA involving a of two stage acid leaching with hydrochloric acid, followed by removal of silica and calcium, reduction of iron, extraction of Ga by foam floatation (polyurethane foam) and finally purification. This method showed that better extraction of Ga occurs at higher acid concentrations, low temperatures, short extraction times and smaller particle size. However, acid leaching is costly, requires better acid resistant equipment, and better environmental protection. Arroyo et al. (2009) discussed a water leaching process for extracting Ge from CFA, followed by solvent extraction. In this process, Ge complexation achieved with catechol, then extraction of the Gecatechol complex with an organic reagent such as trioctylamine diluted in an organic solvent, and finally, stripping $\mathrm{Ge}$ from the organic extract by $\mathrm{NaOH}$. This process extracted $95 \%$ of the Ge from the leachate. In another study, Font et al. (2005) invented a low cost and environment friendly process for the recovery of Ge, where the CFA is leached in water at different ash/water ratios and temperatures. Results showed that temperature is the most important parameter in the extraction process, maximum content (up to $86 \%$ ) of the Ge extracted at $90{ }^{\circ} \mathrm{C}$. For the recovery of Ge from solution, Hernandez-Exposito et al. (2006) developed an ion flotation method using different complexing agents (pyrogallol, catechol, hydroquinone and resorcin) at $\mathrm{pH}$ range of 4-7. It was found that using dodecyl amine as a surfactant, and pyrogallol or catechol as a complexing agent at $\mathrm{pH}$ values of $4-7,100 \%$ of the $\mathrm{Ge}$ could be recovered in 30 min. Torralvo and Fernándezpereira (2011) also reported that catechol as complexing agent for the recovery of $\mathrm{Ge}$ from leachates.

All the above methods were tested on bulk CFA; however, $\mathrm{Ge}$ and $\mathrm{Ga}$ are mainly concentrated in the finer fractions. This was examined in US Patent No. 4686031 (1987), where the process is mainly subjected to size classified CFA, and then extraction by various treatments. It was found that fine fraction, isolating $30 \%$ of the finest particles while avoiding substantial rupturing of cenospheres and plerosphere, provided the best recovery.

\subsection{Molybdenum}

Molybdenum (Mo) is used to produce high tensile strength steel. It is also used as a biocatalyst for plants and animals and it is widely used in the manufacture of super alloys, lubricants, and electronic products. Coal fly ash can provide an alternative source for Mo recovery since some coals are enriched with Mo (Dai et al. 2015a, b). Mok et al. (1984) extracted Mo from CFA using the steps, digestion of CFA using concentrated $\mathrm{HCl}$ and $\mathrm{HNO}_{3}$, diluting the solution using $\mathrm{HCl}$, and selectively extracting Mo from the solution using dithiocarbamate. Ogata et al. (2011) disclosed a method for the recovery of Mo from CFA where the CFA is leached at pH levels 2, 7 and 11, and then adjusted with hydrochloric acid or sodium hydroxide solution. Subsequently, gibbsite (GB), an amorphous aluminium oxide, is used for the adsorption of Mo from elutes from the solutions. A greater concentration of Mo was eluted under acidic conditions onto GB400 (gibbsite calcinated at $400{ }^{\circ} \mathrm{C}$ ) at $\mathrm{pH} 2$ than from neutral or basic eluates. Recovery of Mo from eluates was $90 \%$ using GB400. The main adsorption mechanism was ion exchange with a number of the hydroxyl groups in GB.

\subsection{Lithium}

There are a number of applications used for lithium carbonate, including as an additive in aluminum smelting, production of glasses, enamels, and ceramics, and production of electronic grade crystals. Its pure form is used in lithium ion batteries. Lithium has been found enriched in coal deposits (Qin et al. 2015b). US Patent No. 3857920 (1974) describes a method for the recovery of lithium carbonate from slurries resulting from the dispersion of CFA in water. In this method, CFA slurry is treated with carbon dioxide to convert the lithium carbonate to the more soluble lithium bicarbonate. The resulting bicarbonate solution is then filtered to remove insoluble material. The filtrate containing lithium bicarbonate is decarbonated either by vacuum treatment, heat, or preferably by aeration of the solution to precipitate lithium carbonate in the 
aqueous medium. The precipitated lithium carbonate is then filtered from the aqueous solution. This method is inexpensive and it recovered $80 \%-90 \%$ of the lithium carbonate.

\subsection{Selenium}

Selenium (Se) is mainly used in glassmaking and for pigments. It is also used for making semiconductors and in photocells. Selenium is commercially extracted as a byproduct in the refining of metal sulfide ores, most often during copper production. It can also be extracted from CFA since some coals are enriched in Se (Dai et al. 2014a, b; 2015b, c). Wang et al. (2007) studied the leaching of selenium from bituminous and sub-bituminous coal ash with respect to $\mathrm{pH}$. Very low concentrations of selenium were released at a $\mathrm{pH}$ range from 3 to 4 , while the amount increased with increasing $\mathrm{pH}$ above 4 , and the maximum amount of $\mathrm{Se}(55 \%-69 \%$ of the total) was leached at $\mathrm{pH}$ 12. Iwashita et al. (2005) also reported that leaching of Se increased when $\mathrm{pH}$ was raised. However, recovery of this element is not attempted in these literatures.

\subsection{Radioactive elements}

Radioactive elements have many industrial and scientific applications, despite the obvious dangers if they are not handled properly. Radioactive elements are used as tracers in the medical field, the generation of electricity in nuclear power plants and in the production of nuclear weapons. Coal contains significant amounts of radioactive elements such as uranium (U) (Dai et al. 2015a, c). Thus, CFA can be alternative source of these elements. Sparton Resources Inc. (2007) reported the extraction of $U$ from CFA. This process included acid leaching $\left(\mathrm{H}_{2} \mathrm{SO}_{4}\right)$ and formation of yellowcake by passing the filtered leachate solution through a standard ion exchange resin, stripping the resin and precipitating a $\mathrm{U}$ compound. This process is essentially similar to the $\mathrm{U}$ extraction method used by the primary $\mathrm{U}$ ore processing plants. However, this work is preliminary and requires further work to improve recovery.

Maslov et al. (2010) discussed a method for recovering $\mathrm{U}$ from brown coal ash of Mangolia where the ash is leached with an acid mixture $\left(8 \mathrm{M} \mathrm{HNO}_{3}+10 \% \mathrm{HF}\right)$. The acid mixture leached $U$ and $\mathrm{Ra}$ as high as $99 \%$ and $97 \%$, respectively. The extraction of $U$ from the solution and its purification for the removal of accompanying elements were carried out using an anion exchanger (Dowex 2X8) with a $2 \mathrm{M} \mathrm{HCl}$ solution as the eluate. After leaching, the CFA contained neither natural radioactive elements nor their decay products, thereby allowing for the use of the ash as a building material.

\subsection{Gold, silver and platinum group of elements}

Precious metals such as gold (Au) and silver (Ag) have many application in industry, jewelry and medicine (Guerra and Calligaro 2003; Drake and Hazelwood 2005; Eisler 2003). Some Au compounds are used as anti-inflammatory drugs in the treatment of rheumatoid arthritis and Ag compounds are used in the treatment of infections. Gold is also found in electronic apparatus and Ag is used in photography, industry and for hard solder.

US Patent Nos. 6827837B2 (2004) and 0056548A1 (2005) released a method for the recovering of gold and one and more platinum group elements, such as platinum, rhodium, ruthenium, osmium and iridium, from CFA. In this method an ash formed by the combustion of a preselected coal is mixed with the ash contains gold and one more platinum group of elements, an inquart containing gold and one or more platinum group elements, and fluxing agent to form a 'charge'. The 'charge' is then heated in a furnace to a preselected temperature and forming a molten charge including a molten inquart; absorbing a portion of the gold and more platinum group elements of the ash into the molten inquart. Casting a dare bar (which contains gold and one or more platinum group elements) by discharging the molten inquart. Digesting the dore bar in an elctrowinning process where the dore bar is introduced as an anode in an acidic bath and an electrical potential is maintained between the cathode and anode, then precipitating and dissolving trace elements in the electrolytic solution producing an anode slime. The digestion of anode slimes is done using $30 \%$ solution of $\mathrm{HNO}_{3}$. The digestion is filtered and rinsed then the liquid rinsed portion containing $\mathrm{Ag}$ in solution is washed with $\mathrm{HCl}$ and filtered. The residue is mixed with aqua regia, forming a solution containing gold, platinum and palladium. Gold may then be removed by solvent extraction. Rhodium and other metals may be removed by precipitation by the treatment of the solution with potassium hydroxide and sodium borohydrite. Palladium in solution may be removed by precipitation by treatment with ammonium hydroxide, $\mathrm{NH}_{4} \mathrm{OH}$, and $\mathrm{HCl}$ as the complex $\mathrm{PdCl}_{2}\left(\mathrm{NH}_{3}\right)_{2}$. Alternatively, $\mathrm{Pd}$ in solution is removed by precipitation with DiMethyl Glyxime, followed by filtration and reduction and ashing of the residue. Platinum in solution is removed by any of the accepted methods including precipitation as impure $\left(\mathrm{NH}_{4}\right)_{2} \mathrm{PtCl}_{6}$ after treatment with $\mathrm{NH}_{4} \mathrm{Cl}$, or leaching $\mathrm{H}_{2}$ $\mathrm{PdCl}_{4}$ from solution. An organic solvent such as DiMethyl Glyoxime is used to extract gold, after treatment with $\mathrm{NH}_{4} \mathrm{Cl}$, the solution should also be treated with ethanol and hydrogen peroxide. The solution is filtered and the residue, including $\left(\mathrm{NH}_{4}\right)_{2} \mathrm{PtCl}_{6}$, subjected to reduction and burning leaving an impure platinum sponge. The platinum sponge can be purified by redissolving in aqua-regia. This method 
is very complex, and a recovery and purity level is not mentioned.

\subsection{Rare earth elements (REEs)}

Rare earth elements include light REEs ( $\mathrm{Sc}, \mathrm{La}, \mathrm{Ce}, \mathrm{Pr}, \mathrm{Nd}$, and $\mathrm{Pm}$ ), medium REEs (Sm, Eu and Gd) and heavy REEs ( Tb, Dy, Ho, Er, Tm, Yb, Lu and Y), which are mainly used is various industrial purposes such as fuel cells, green energy devices, hi-capacity batteries, magnets for wind generation (Chen 2011; Hoenderdal et al. 2013; Franus et al. 2015). REEs have been recovered from bauxite residue (Borra et al. 2015) and electronic wastes (Anonymous 2015). It has also been recognized that some coals (Seredin 1996; Dai et al. 2014a, b) and CFA (Ketris and Yudovich 2009; Blissett et al. 2014; Dai et al. 2012a, b; Dai et al. 2014a, b; Franus et al. 2015) are enriched with REE; thus, recently sparking interest in evaluating of this product as a potential alternative source of REEs (Seredin et al. 2013).

There are several methods developed for recovery of rare elements from CFA, the chlorination method is favored due to selectivity and high reactivity. The necessary apparatus required for this process is very expensive. This technique can be used to recover only certain rare elements where other complex recovery processes are not suitable. From this standpoint, US Patent No. 4649031 (1987) reported a non-destructive digestion process for the recovery of rare elements, including Lanthanides and Actinides and group V and VI elements that are adsorbed onto the surfaces of coal combustion residues. This techniques includes: (1) reducing the grain size of the combustion residues from 0.1 to $1 \mathrm{~mm}$, (2) digestion of the residues with water, (3) digestion of the residues with a dilute aqueous alkali solution $(1.5 \%-8 \%)$, (4) digestion of the residue with a dilute aqueous acid solution ( $0.5 \%$ $5 \%)$ at a temperature below the boiling point of water, (5) separating the solid and liquid phases after each digestion, (6) and isolating the $\mathrm{s}$ metals from the liquid phases. This study shows that the mild digestion agents used dissolve an unexpectedly high proportion of rare metals present in the byproducts and that increasing the heat and residence time lowers the availability of the metals. This process is not appropriate for the recovery of individual elements from the mixed solution.

Recently, US Patent No. 0287653A1 (2013) demonstrated the recovery of REEs from CFA. In this method, first the CFA was treated with a mineral acid $\left(\mathrm{HNO}_{3}\right)$ at $90{ }^{\circ} \mathrm{C}$ to form a more concentrated mineral acid solution. This solution is mixed with an organic solution (tributyl phosphate and kerosene) that includes the rare earth salts. The organic solution is mixed with water to form an aqueous solution. REEs substantially recovered from the aqueous solution by using ion exchange process. In a continuation-in-part of the above patent, US Patent No. 0139871 (2015) was carried out using the same method, but here the CFA was sorted into a substantially magnetic and non-magentic fraction. This indicates magnetic treatment can maximize efficiency of extracting REEs from CFA. However, extraction efficiency of these methods is not reported. Furthermore, ion exchange method can remove other metals from the solution. This method needs to be optimized to improve the yields for REEs.

\subsection{Other trace elements $(\mathrm{Pb}, \mathrm{Cr}, \mathrm{Cd}$, and $\mathrm{Cu})$}

Coal fly ash also contains considerable amounts of trace and rare elements, and some them can be hazardous (Izquierdo and Querol 2012). There are many studies which focused on the extraction of trace metals from CFA, some employing hydrometallurgical techniques using various lixiviants: inorganic acids such as sulfuric acid, hydrochloric acid, nitric acid, organic acid such as acetic acid, citric acid, oxalic acid, alkaline reagents such as sodium and ammonium hydroxide, chelating reagents such as ethylendiaminetetraacetate (EDTA) and diethylenetriaminepentaacetate (DTPA) (Hong et al. 2000; Zhang and Itoh 2006).

Narukawa et al. (2007) studied Cr extraction from an Australian CFA using $0.01 \mathrm{M} \mathrm{NaOH}$. However, this process did not leach $\mathrm{Cr}$ (III) from the CFA. Huang et al. (2011) discussed the alkaline leaching by ammonium or sodium hydroxide, where only $\mathrm{Pb}$ and $\mathrm{Zn}$ are recovered while other metals remained in the solid residues. However, this process can extract other heavy metals such as $\mathrm{Cu}$ and $\mathrm{Cd}$ if the leaching process is conducted together with subsequent leaching using acidic lixiviants. Okada et al. (2007) reported that in acidic leaching using acetic acid recovered $97 \%$ of $\mathrm{Zn}$ and $98 \%$ of $\mathrm{Pb}$ from CFA, while the same CFA in alkaline leaching using $3 \mathrm{M} \mathrm{NaOH}$ recovered $81 \% \mathrm{~Pb}$ and $35.5 \% \mathrm{Zn}$. Consequently, acid leaching is more effective under hydrothermal conditions. This was studied by Zhang and Itoh (2006) for CFA using five types of acids and hydrochloric acid was found to be the most effective for metal extraction from the CFA. Compared to room conditions (standard temperatures and pressures), it was determined that hydrothermal treatment accelerated the dissolution of the CFA and resulted in better leaching of metals such as $\mathrm{Cr}, \mathrm{Cd}$, and $\mathrm{Pb}$. Even more effective leaching can be done using chelating agents. Hong et al. (2000) studied the extraction of heavy metals from CFA using acid and chelating agents such as nitritriacetic acid (NTA) and ethylendiaminetetraacetate (EDTA), or diethylenetriaminepentacetate (DTPA). The results showed that chelating agents provide good leaching efficiency and after the treatment the CFA's were successfully detoxified 
to meet landfilling guidelines. Using $3.0 \%$ EDTA or DTPA, $20 \%-50 \% \mathrm{Cr}, 60 \%-95 \% \mathrm{Cu}, 60 \%-100 \% \mathrm{~Pb}$, and $50 \%-100 \% \mathrm{Zn}$ were extracted from CFA. However, these agents are not biodegradable and it is difficult to recover the metals from the leachate due to their strong chelating properties.

Recovery of metals from CFA using bioextractants has been studied by many authors (Seidel et al. 2001; Ishigaki et al. 2005; Sierra-Alvarez 2009). This process is important at an industrial scale. In this process, chemolithoautotrophic bacteria such as Thiobacillus species and Heterotrophic fungi such as Aspergillus and Penicillium species are used to leachthe metals. The leached metals can then be recovered and the residues may be safely utilized. US Patent No. 5278069 (1994) discusses the bioextraction process using strains of Rhodococcus and Thiobacillus thiooxidans for the removal of Co along with other metals (Al, Ti and Fe) from CFA. After extraction, the metals were recovered in a series of precipitation steps by controlling $\mathrm{pH}$. This technique is relatively inexpensive and requires low energy inputs when compared with conventional technologies (Krebs et al. 1997). However it is a slow process requires sufficient amounts of cell culture and is not selective toward specific metals (Groudev et al. 1982).

\section{Recovery of other materials}

\subsection{Magnetic materials}

Magnetite or other magnetic material is used by the steel industry for cleaning coal prior to combustion. One potential source of magnetite is CFA which can contains economically recoverable amounts of magnetic material. After removal of magnetic material from CFA, the remaining product can be useful for refractory and ceramic manufacturing since it contains appreciable amounts of $\mathrm{Al}_{2} \mathrm{O}_{3}$ and $\mathrm{SiO}_{2}$ (Rao et al. 1999). The characteristics of magnetic material in CFA vary depending on the coal source and operating conditions of the coal boiler (Zyryanov et al. 2011). The basic principle behind magnetic separation deals with the fact that materials having different magnetic moments experience varying forces in the presence of a magnetic field gradient. Thus, applying an external magnetic field can extract those materials with similar magnetic properties (Yavuz et al. 2009).

There are many wet or dry magnetic separation methods for the recovery of magnetic materials from CFA. The dry process uses a rotating magnetic drum and initial separation produces middling and tailings which are discarded and a crude iron oxide fraction which must be further refined by passing it through another magnetic unit. The wet process involves pumping CFA slurry into a magnetic drum where the magnetic iron oxides and associated materials are collected and then the material is passed through a similar unit for further refining. In most of the plants using wet magnetic separation, the advantage as that the slurry can be directly fed into the feed tank. Prakash et al. (2001) demonstrated the use of a selective magnetic coating for the removal of iron from Talcher (India) CFA. They used sodium hexametaphophate (NaHMP) as a dispersing solution, followed by sodium oleate for the separation of iron from. The recovery rate for Fe was around $92 \%$. The wet/dry magnetic separations processes are documented by numerous US Patents (Nos. 4191336 1980; 4319988 1982; 5047145 1991; 5227047 1993). However, these methods are not cost-effective if the ash contains less than $2 \%$ magnetite. In order to improve the process or more recovery, CFA containing sufficient amount of magnetic material ( $>2 \%$ ) need to be selected. Groppo and Honaker (2009) studied the economic recovery of magnetite material from CFA.

US Patent No. 3769054 (1993) released another method for the recovery of magnetic materials from CFA. In this method CFA is dry processed in an air classifier and then separated the magnetic separation. This process is expensive, and the recovered portion of magnetite often contains undesirable impurities. To resolve these problems, US Patent No. 4191336 (1980) provides an improved process for the recovery of high purity magnetite from CFA. This process involves making a water slurry of the CFA and then passing the concentrated slurry through the magnetic separators; magnetite is contained in the separated material. The separated magnetite is then pulverized to a size where $95 \%$ of the magnetite will pass through a 325 mesh sieve. The crushed magnetite is passed through a third separator followed by purification and drying.

\subsection{Cenospheres}

Cenospheres are composed mainly of silica, alumina and iron oxides, and have unique properties such as sphericity, inert, lower density than water, and they are waterproof making them useful in a variety of applications. Generally, cenospheres make up $1 \%-3 \%$ by weight of the total CFA produced. They have valuable industrial applications, such as oil well drilling, ceramics, plastic, paint, coatings, polymer fillers, building products, buoyaancy, and as low dielectric constant substrates (Huo et al. 2009; Wang et al. 2011). Cenospheres are used for water purification such as the removal of excess fluoride from drinking water. In this process, magnesia loaded cenospheres are produced using a relatively simple wet impregnation method with magnesium chloride (Xu et al. 2011). Cenospheres are used as a carrier because of their low weight, sphericity, non- 
toxicity, and high strength. They are ideal for incorporation into materials such as silicone rubber in order to increase the conductivity. In addition, they enhance the rubber's suitability as an electromagnetic wave absorbing material, which can be used in electronic and radar applications (Pang et al. 2011).

There are several methods for the separation of cenospheres from CFA. Traditionally, cenospheres were removed from CFA via float-sink in settling lagoons. This simple procedure allows potentially toxic elements to be leached and requires a large space and significant time (Hirajima et al. 2010). Alternatively, a triboelectric separation system was used (Gurupira et al. 2001) but this technique requires that the spheres have a specific gravity $\leq 1$. Some solid silica particles with specific gravity of $\geq 1$ may contain gas bubbles which over their specific gravity so that they mimic cenospheres during this process, rendering it less effective and attractive. Other studies that have looked at the extraction of cenospheres on a wet basis. In US Patent No. 4121945 (1978), CFA is mixed with water to form a slurry then a frothing agent is added and cenospheres lighter than water are skimmed. US Patent No. 4652433 (1987) looked at another method where CFA is separated into fine and coarse fractions and the coarse fraction is then mixed with water, subsequently the cenospheres are removed by skimming. These methods have some disadvantages. Wet processing caused environmental problems and imposed space restrictions. In addition, these methods only collect cenospheres with specific gravity $\leq 1.0$; those that float on water. Also, these processes are not suitable for CFA that contains $10 \%$ or more lime because high Ca bearing CFA (such as ASTM C618 Class $\mathrm{C}$ fly ash) has cementations properties when mixed with water and when pozolanic reactions occur the material may harden. When using these wet methods many cenospheres can be trapped in agglomerated and/or hardened masses before flotation occurs. This problem was solved by a few recent US Patents (No. 0190327A1 2008, No. 8074804B2 2011, and No. 0050519A1 2012) where cenospheres were separated from CFA in a dry state by using air as the fluid media for the separation. In one of the processes, CFA is separated into narrow particle size fractions, followed by density separation using a fluidized bed of air, preferable in the absence of water by dry screening, and then an optional further particle size separation. The advantages of this technique are that it can yield nearly $100 \%$ cenospheres and it avoids agglomeration of ash having high $\mathrm{Ca}$ content.

\subsection{Unburned carbon}

Unburned carbon in CFA can be used during activated carbon preparation or carbon black, and can be used as a supplementary fuel. It can also be useful in the manufacture of graphite (Cabielles et al. 2008; Cameán and Garcia 2011). Removal of unburned carbon from coal ash makes it a more valuable cement additive. There are numerous methods for the recovery of unburned carbon from CFA (Hwang et al. 2002). Electrostatic separation is one of them, has been used by many authors (Gray et al. 2002; Soong et al. 2002). This method operates in a controlled electrode potential condition following the principle of bipolar charging of dry particles either by particle-particle contact or by particle-wall collision under turbulent conditions. This process separates the positively charged carbon particles from the negatively charged ash particles. This technology has been successfully commercialized.

One of the most promising methods for recovering unburned carbon from CFA is froth flotation. This method relies on the ability of air bubbles to selectively adhere to the surface of a particular mineral surface. Since carbon is hydrophobic in nature, other particles that are hydrophilic attached to the air bubbles and become positively buoyant and float on the slurry (Ucurum 2009). This process has been commercialized in the US for CFA beneficiation with reported carbon grade recoveries of up to $70 \%$ (Baltrus et al. 2001).

A similar technology for froth flotation uses oil agglomeration, which involves wetting hydrophobic particles by adding oil to the aqueous slurry. Subsequently, the vessel can be agitated which allows the oil coated particles to collide with each other and form agglomerates. The oil/carbon agglomerates being less dense than the ash suspension rise to the top of the vessel (Mehrotra et al. 1983). US Patent No. 546363 (1995) removes carbon adding floating reagent-mixture of fuel oil and petroleum sulfonate (10:1) and has recovered $44 \%$ after 1 min of flotation while fuel oil flotation after $20 \mathrm{~min}$ recovered only $38 \%$. Gray et al. (2001) used this method with cyclohexane as the solvent, and achieved high carbon recoveries (55\%-57\%). There are other studies reporting similar carbon purities in their agglomerates using vegetable oil as their solvent (Alonso et al. 1999). US Patent No. 6068131 (2000) describes this type of removal using a conditioning agent such as biodegradable soil.

\section{Conclusions}

Coal fly ash has been explored as an alternative source of various valuable elements and minerals. Recovery of these components from CFA not only provides alternative resources, but also reduces disposal cost and protects the environment. This paper has reviewed a number of hydrometallurgical methods developed for the recovery of those products from CFA and highlighted suitability and effective technique for their extraction based on US Patents 
and journal literature. By applying those techniques, it was found that the recovery of major elements such as $\mathrm{Fe}, \mathrm{Al}$ and $\mathrm{Si}$ and trace elements such as Ge and Ga from CFA are satisfactory. However, for other trace and rare earth elements further research is needed to develop adequate results in terms of selective recovery and purification. Mineral matter such as cenospheres, unburned carbon and magnetic materials also significantly extracted from CFA.

Most of these methods were studied at lab-scale, their commercialization utilization is largely limited, and therefore further development in large scale is required to scale up to commercial production levels. In addition, economic viability and environmental impact evaluation of each method should be focused in the future work. This would be helpful to choosing correct method and to ensure that any operations don't result in a greater environmental footprint than mining of primary resources. Quality of raw ash obtained in parallel with the metal recovery processes needs to be assessed.

Open Access This article is distributed under the terms of the Creative Commons Attribution 4.0 International License (http://crea tivecommons.org/licenses/by/4.0/), which permits unrestricted use, distribution, and reproduction in any medium, provided you give appropriate credit to the original author(s) and the source, provide a link to the Creative Commons license, and indicate if changes were made.

\section{References}

Ahmaruzzaman M (2010) A review on the utilization of fly ash. Prog Energy Combust Sci 36:327-363

Alam J, Akhtar MN (2011) Fly ash utilization in different sectors in Indian scenario. Int J Emerg Trends Eng Dev 1:1-13

Alonso MI, Martínez-Tarazona RM, García AB (1999) Coal recovery from coal fines clearing wastes by agglomeration with vegetable oils: effect of oil type and concentrations. Fuel 78:753-759

Aldrich RG (1982) Separation of high grade magnetite from fly ash. US Patent No. 4319988

Anonymous (2015) Recovery of rare earths from electronic wastes; an opportunity for High-Tech SMEs. Directorate General for Internal Policies, Policy Department A: Economic and Scientific Policy, European Parliament. http://www.europarl.europa.eu/ RegData/etudes/STUD/2015/518777/IPOL_STU(2015)518777_ EN.pdf)

Arroyo F, Fernandez-Pereira C, Olivares J, Coca P (2009) Hydrometallurgical recovery of germanium from coal gasification fly ash. Ind Eng Chem Res 48:3573-3579

Arroyo F, Font O, Chimenos JM, Pereira CF, Querol X, Coca P (2014) IGCC fly ash valorisation. Optimisation of Ge and Ga recovery for an industrial application. Fuel Process Technol 124:222-227

Ashworth RA et al. (1987) Method for the recovery of minerals and production of by-products from coal ash. US Patent No. 4652433

Bai G, Teng W, Wang X, Qin J, Xu J, Li P (2010) Alkali desilicated coal fly ash as substitute of bauxite in lime-soda sintering process for aluminium production. Trans Nonferr Met Soc China 20:169-175

Baltrus JP, Wells AW, Fauth DJ, Diehl JR, White CM (2001) Characterization of carbon concentrates from coal-combustion fly ash. Energy Fuels 15:455-462
Basu M, Pande M, Bhadoria PBS, Mahapatra SC (2009) Potential flyash utilization in agriculture in agriculture: a global review. Prog Nat Sci 19:1173-1186

Barclay KM (1983) Recovery of vanadium from carbonaceous materials. US Patent No. 4420464

Benson S, Laumb M (2007) Removal and recovery of deposits from coal gasification systems. US Patent No. 20070274886A1

Blander M et al. (1984) Extraction of trace metals from fly ash. US Patent No. 4475993

Blissett RS, Rowson NA (2012) A review of the multi-component utilization of coal fly ash. Fuel. doi:10.1016/j.juel.2012.03.024

Blissett RS, Smalley N, Rowson NA (2014) An investigation into six coal fly ashes from the United Kingdom and Poland to evaluate rare earth element content. Fuel 119:236-239

Borra CR, Pontikes Y, Binemans K, Gerven TV (2015) Leaching of rare earths from bauxite residue (red mud). Miner Eng 76:20-27

Burnet O, Murtha MJ, Wijatno H (1977) Recovery of alumina from fly ash by high temperature chlorination. In: Rose JG (ed) Proceeding 3rd Kentucky coal refuse disposal and utilization seminar, May 11-12. University of Kentucky, Lexington, pp 83-88

Butterman WC, Jogerson JD (2005) Mineral commodity profiles: germanium. U.S. Geological Survey, U.S. Department of the Interior, Washington, DC

Brown JW (1980) Process for recovering magnetite from fly ash. US Patent No. 4191336

Cabielles M, Montes-Morán MA, Garcia AB (2008) Structural study of graphite materials prepared by HTT of unburned carbon concentrates from coal combustion fly ashes. Energy Fuels 22:1239-1243

Cameán I, Garcia AB (2011) Graphite materials prepared by HTT of unburned carbon from coal combustion fly ashes: performance as anodes in lithium-ion batteries. J Power Sources 196:4816-4820

Cao D, Selic E, Herbell JD (2008) Utilization of fly ash from coalfired power plants in China. J Zhejiang Univ 9:681-687

Chandrashekhar S (2010) Process for obtaining treated coal and silica from coal containing fly ash. US Patent No. 2010/0287827A1

Chen Z (2011) Global rare earth resources and scenarios of future rare earth industry. J Rare Earths 29:1-6

Clark LB, Sloss LL (1992) Trace elements-emissions from coal combustion and gasification. IEA Coal Research Rep. No. IEACR/49

Corigliano F et al. (1989) Process for the high-yield recovery of vanadium from petroleum combustion residues. US Patent No. 4814150

Dai S, Jiang Y, Ward C, Gu L, Seredin VV, Liu H, Zhou D, Wang X, Sun Y, Zou J, Ren D (2012a) Mineralogical and geochemical compositions of the coal in the Guanbanwusu Mine, Inner Mongolia, china: further evidence for the existence of an $\mathrm{Al}(\mathrm{Ga}$ and REE) ore deposit in the Juangar Coalfield. Int J Coal Geol 98:10-40

Dai S, Wang X, Seredin VV, Hower JC, Ward CR, O'Keefe JMK, HuangW Li T, Li X, Liu H, Xue W, Zhao L (2012b) Petrology, mineralogy, and geochemistry of the Ge-rich coal from the Wulantuga Ge ore deposit, Inner Mongolia, China: new data and genetic implications. Int J Coal Geol 90-91:72-99

Dai S, Luo Y, Seredin VV, Ward CR, Hower JC, Zhao L, Liu S, Zhao C, Tian H, Zou J (2014a) Revisiting the late Permian coal from the Huayingshan, Sichuan, southwestern China: enrichment and occurrence modes of minerals and trace elements. Int $\mathrm{J}$ Coal Geol 122:110-128

Dai S, Seredin VV, Ward C, Jiang J, Hower J, Song X, Jiang Y, Wang X, Gornostaeva T, Li X, Liu H, Zhao L, Zhao C (2014b) Composition and modes of occurrence of minerals and elements in coal combustion products derived from high-Ge coals. Int $\mathbf{J}$ Coal Geol 121:79-97 
Dai S, Seredin VV, Ward CR, Hower JC, Xing Y, Zhang W, Song W, Wang P (2015a) Enrichment of U-Se-Mo-Re-V in coals preserved within marine carbonate successions: geochemical and mineralogical data from the late Permian Guiding Coalfield, Guizhou, China. Miner Depos 50:159-186

Dai S, Liu J, Ward CR, Hower JC, Xie P, Jiang Y, Hood MM, O'keefe JMK, Song H (2015b) Petrological, geochemical, and mineralogical compositions of the low-Ge coals from the Shengil Coalfield, China: a comparative study with Ge-rish coals and a formation model for coal-hosted Ge ore deposit. Ore Geol Rev 71:318-349

Dai S, Yang J, Ward CR, Hower JC, Liu H, Garrison TM, French D, O'Keefe JMK (2015c) Geochemical and mineralogical evidence for a coal-hosted uranium deposit in the Yili Basin, Xinjiang, northwestern China. Ore Geol Rev 70:1-30

Dhadse S, Kumari P, Bhagia LJ (2008) Fly ash characterization and utilization and government initiatives in India: a review. J Sci Ind Res 67:11-18

Drake PL, Hazelwood KJ (2005) Exposure-related health effects of silver and silver compounds: a review. Ann Occup Hyg 49:575-585

Eisler R (2003) Chrysotherapy: a synoptic review. Inflamm Res $52: 487-501$

Fang Z, Gesser HD (1996) Recovery of gallium from coal fly ash. Hydrometallurgy 41:187-200

Fass R et al. (1994). Bioleaching method for the extraction of metals from coal fly ash using thiobacillus. US Patent No. 5278069

Font O, Querol X, Lopez-Soler A, Chimenos JM, Fernandez AI, Burgos S, Garcia PF (2005) Germanium extraction from gasification fly ash. Fuel 84:1384-1392

Fontana D, Kulkarni P, Pietrelli L (2005) Extraction of titanium (IV) from acidic media by 2-ethylhexyphosphonic acid mono-2ethylhexyl ester. Hydrometallurgy 77:219-225

Franus W, Wiatros-Motyka MM, Wdowin M (2015) Coal fly ash as a resource for rare Earth elements. Environ Sci Pollut Int 22:9464-9474

Gardner HE (1989) Recovery of vanadium and nickel from petroleum residues. US Patent No. 4816236

Gieré R, Carleton LE, Lumpkin GR (2003) Micro- and nanochemistry of fly ash from a coal-fired power plant. Am Miner 88:853-1865

Gluskoter HJ, Ruth RR, Miller WG, Cahill RA, Dreher GB, Kuhn JK (1977) Trace elements in coal: occurrence and distribution. Illinois State Geological Survey, Circular 499

Grantham L et al (1974) Recovery of lithium carbonate. US Patent No. 3857920

Gray ML, Champagne KJ, Soong Y, Finseth DH (2001) Parametric study of the column oil agglomeration of fly ash. Fuel 80:867-871

Gray ML, Champagne KJ, Soong Y, Killmeyer RP, Maroto-Valer MM, Anderson JM, Ciocco MV, Zandhuis PH (2002) Physical cleaning of high carbon fly ash. Fuel Process Technol 76:11-21

Gropp JG et al. (1995) Method of removing carbon from fly ash. US Patent No. 546363

Groppo J, Honaker R (2009) Economic recovery of fly ash derived magnetics and evaluation for coal cleaning. In: World of coal ash conference, Lexington

Groudev SM, Gencev FN, Groudeva VI (1982) Use of microorganisms for recovery of aluminum from alumino silicate. Achiev Prospect Travaux 12:203-212

Guerra MF, Calligaro T (2003) Gold cultural heritage objects: a review of studies of provenance and manufacturing technologies. Meas Sci Technol 14:1527-1537

Gurupira T, Jones CL, Howard A, Lockert C, Wandell T, Stencel JM (2001) New products from coal combustion ash: selective extraction of particles with density less than 2 . In: International ash utilization symposium, Lexington, Kentucky
Gutiérrez B, Pazos C, Coca J (1997) Recovery of gallium from coal fly ash by a dual reactive extraction process. Waste Manag Res $15: 371-382$

Halina M, Ramesha S, Yarmob MA, Kamarudin RA (2007) Nonhydrothermal synthesis of mesoporous materials using sodium silicate from coal fly ash. Mater Chem Phys 101:344-351

Harvey RD, Cahill RA, Chou CL, Steele JD (1983) Mineral matter and trace elements in the Herrin and springfield coals, Illinois basin coal field. ISGS Contract/Grant Report 1983-4

Heidrich C, Feuerborn HJ, Weir A (2013) Coal combustion products: a global perspective. In: World of coal ash (WOCA) conference-April 22-25, 2013, Lexington

Hernandez-Exposito A, Chimenos JM, Fernandez AI, Font O, Querol X, Coca P, Garcia PF (2006) Ion flotation of germanium from fly ash aqueous leachates. Chem Eng J 118:69-75

Hill RO et al. (1981) Process of extraction of aluminium values from coal ash. US Patent No. 4243640

Hirajima T, Petrus HTBM, Oosako Y, Nonaka M, Sasaki K, Ando T (2010) Recovery of cenospheres from coal fly ash using a dry separation process: separation estimation and potential application. Int J Miner Process 95(1-4):18-24

Hoenderdal S, Espinoza LT, Marscheider-Weidemann F, Grus W (2013) Can a dysprosium shortage threaten green energy technologies? Energy 49:344-355

Hong K, Tokunaga S, Kajiuchi T (2000) Extraction of heavy metals from MSW incinerator fly ashes by chelating agents. J Hazard Mater B75:57-73

Huang K, Inoue K, Harada H, Kawakita H, Ohto K (2011) Leaching behavior of heavy metals with hydrochloric acid from fly ash generated in municipal waste incineration plants. Trans Nonferr Met Soc China 21:1422-1427

Huo P, Yan Y, Li S, Li H, Huang W (2009) Preparation and characterization of cobalt sulfophthalocyanine/ $\mathrm{TiO}_{2} / \mathrm{fly}$-ash cenospheres photocatalyst and study on degradation activity under visible light. Appl Surf Sci 255:6914-6917

Hurst SL et al. (1978) Fly ash beneficiation process. US Patent No. 4121945

Hwang JY (1991) Wet Process for fly ash beneficiation. US Patent No. 5047145

Hwang JY (1993) Wet process for fly ash beneficiation. US Patent No. 5227047

Hwang JY, Sun X, Li Z (2002) Unburned carbon from fly ash for mercury adsorption: I. Separation and characterization of unburned carbon. J Miner Mater Charact Eng 1:39-60

Ilic M, Cheeseman C, Sollars C, Knight J (2003) Mineralogy of microstructure of sintered lignite coal fly ash. Fuel 82:331-336

Ishigaki T, Nakanishi A, Tateda M, Ike M, Fujita M (2005) Bioleaching of metal from municipal waste incineration fly ash using a mixed culture of sulfur-oxidizing and iron-oxidizing bacteria. Chemosphere 60:1087-1094

Iwashita A, Sakaguchi Y, Nakajima T, Takanashi H, Ohki A, Kambara S (2005) Leaching characteristics of boron and selenium for various coal fly ashes. Fuel 84:479-485

Izquierdo M, Querol Z (2012) Leaching behaviour of elements from coal combustion fly ash: an overview. Int $\mathrm{J}$ Coal Geol 94:54-66

Jianguo Q et al. (2010) Process for recovery of silica followed by alumina from coal fly ash. US Patent No. 0119426A1

Jianguo Q et al. (2011) Process for recovery of silica followed by alumina from coal fly ash. US Patent No. 7871583B2

Jha VK, Matsuda M, Miyake M (2008) Resource recovery from coal fly ash waste: an overview study. J Ceram Soc Jpn 116:167-175

Joshi PB et al. (2015) Recovery of rare earth elements and compounds from coal ash. US patent No. 8968688B2

Joshi PB et al. (2013) Recovery of rare earth elements and compounds from coal ash. US patent No. 0287653A1 
Karayigit AI, Onacak T, Gayer RA, Goldsmith S (2001) Mineralogy and geochemistry of feed coals and their combustion residues from the Cayirhan Power Plant, Ankara, Turkey. Appl Geochem 16:911-919

Ketris M, Yudovich Y (2009) Estimations of Clarkes for carbonaceous biolithes: world averages for trace element contents in black shales and coal. Int J Coal Geol 78:135-148

Krebs W, Brombacher C, Bosshard PP, Bachofen R, Brandl H (1997) Microbial recovery of metals from solids. FEMS Microbiol Rev 20:605-617

Kruger RA (1997) Fly ash beneficiation in South Africa: creating new opportunities in the market place. Fuel 76:777-778

Lisowyi B, Hitchcoc DC (1987) Beneficiation of gallium in fly ash. US Patent No. 4686031

Li L, Wu Y, Liu Y, Zhai Y (2011) Extraction of alumina from coal fly ash with sulfuric acid leaching method. Chin J Process Eng 11(2):254-258

Lisowyj B (1986) Method for extracting of iron, aluminium and titanium from coal ash. US Patent No. 4567026

Lisowyi B et al. (1986) Process for the recovery of gallium and germanium from coal fly ash. US Patent No. 4678647

Lisowyi B et al. (1987) Direct fuel-fired furnace arrangement for the recovery of gallium and germanium from coal fly ash. US Patent No. 4643110

Lisowyi B et al. (1987) Beneficiation of gallium in fly ash. US Patent No. 4686031

Lisowyi B et al. (1988) Condensation sand collection system. US Patent No. 4757770

Lisowyj B et al. (1988) Sand collection system. US Patent No. 4757772

Lakshman et al. (1990) Process for treatment of fly ash. US Patent No. 4966761

Loya MIM, Rawani AM (2014) A review: promising applications for utilization of fly ash. Int J Adv Technol Eng Sci 2(7):143-149

Lu S, Fang RL, Zhao H (2003) Study of recovery of highly pure super-fine powdered aluminum oxide from fly ash by way of lime sintered self powdering. Sci Study 1:15-17

Lukkassen D, Meidell A (2007) Advanced materials and structures and fabrication process. Book manuscript, Narvik University College, HiN

Masaaki N, Yoshihiro K, Setsuo T, Toru E, Iwao N (1996) Method for recovering vanadium from petroleum incineration ash. Mitsubishi Heavy Industries, Ltd. Eu Pat No. JP-A-H08325651

Maslov OD, Tserenpil S, Norov N, Gustova MV, Filippov MF, Belov AG, Altangerel M, Enhbat N (2010) Uranium recovery from coal ash dumps of Mogolia. Solid Fuel Chem 44:433-438

Matjie RH, Bunt JR, Heerden JHP (2005) Extraction of alumina from coal fly ash generated from a selected low rank bituminous South African coal. Miner Eng 18:299-310

Matyas B et al. (1987) Process for recovering rare metals from the combustion residue of coal by digestion. US Patent No. 4649031

Mayfield D, Lewis AS (2013) Environmental review of coal ash as a resource for rare earth and strategic elements. In: World of coal ash (WOCA) conference-April 22-25, 2013 in Lexington

McDowell WJ et al. (1981) Salt-soda sintering process for recovering aluminum from fly ash. US Patent No. 4254088

Meawad AS, Bojinova DY, Pelovski YG (2010) An overview of metals recovery from thermal power plant solid wastes. Waste Manag 30:2548-2559

Mehrotra AK, Behie LA, Bishnoi PR, Svrcek WY (1982a) Hightemperature chlorination of coal ash in a fluidized bed. 1 . Recovery of aluminium. Ind Eng Chem Process Des Dev 21:37-44

Mehrotra AK, Behie LA, Bishnoi PR, Svrcek WY (1982b) Hightemperature chlorination of coal ash in a fluidized bed. 2 .
Recovery of iron, silicon, and titanium. Ind Eng Chem Process Des Dev 21:44-50

Mehrotra VP, Sastry KVS, Morey BW (1983) Review of oil agglomeration techniques for processing of fine coals. Int $\mathbf{J}$ Miner Process 11(3):175-201

Minter BE (2004) Method for recovering of trace elements from coal. US Patent No. 6827837B2

Mitner B (2005) Method for recovering trace elements from coal. US Patent No. 0056548A1

Mok WM, Willmes H, Wai CM (1984) Solvent extraction of molybdenum from biological samples and from coal fly ash for neutron activation analysis. Anal Chem 56:2623-2624

Moskaly RR (2004) Review of germanium processing worldwide. Miner Eng 17:393-402

Moskalyk RR, Alfantazi AM (2003) Processing of vanadium: a review. Miner Eng 16:793-805

Murtha MJ (1983) Process for the recovery of alumina from fly ash. US Patent No. 4397822A

Narukawa T, Riley K, French D, Chiba K (2007) Speciation of chromium in Australian fly ash. Talanta 73:178-184

National Research Council (US) (2006) Managing coal combustion residues in mines. National Academies, p 256

Navarro R, Guzman J, Saucedo I, Revilla J, Guibal E (2007) Vanadium recovery from oil fly ash by leaching, precipitation and solvent extraction processes. Waste Manag 27(3):425-438

Nayak N, Panda CR (2010) Aluminium extraction and leaching characteristics of Talcher thermal power station fly ash with sulphuric acid. Fuel 89(1):53-58

Ogata F, Tominaga H, Yabutani H, Taga A, Kawasaki N (2011) Recovery of molybdenum from coal by gibbsite. Toxicol Environ Chem 93:635-642

Okada T, Tojo Y, Tanaka N, Matsuto T (2007) Recovery of zinc and lead from fly ash from ash-melting and gasification-melting processes of MSW-comparison and applicability of chemical leaching methods. Waste Manag 27:69-80

Padil R, Sohn HY (1985) Sintering kinetics and alumina yield in limesoda sinter process for alumina from coal wastes. Metallurg Mater Trans B 16:385-395

Pang J, LiQ Wang W, Xu X, Zhai J (2011) Preparation and characterization of electroless Ni-Co-P ternary alloy on fly ash cenospheres. Surf Coat Technol 205:4237-4242

Pennachetti J et al. (1973) Process for the treatment of fly ash. US Patent No. 3769054

Prakash S, Mohanty JK, Das B, Venugopal R (2001) Characterisation and removal of iron from fly ash of Talcher Area, Orissa, India. Miner Eng 14:123-126

Prasad B, Mondal KK (2009) Environmental impact of manganese due to its leaching from coal fly ash. J Environ Sci Eng 51(1):27-32

Qin S, Sun Y, Li Y, Wang J, Zhao C, Gao K (2015a) Coal deposits as promising alternative sources for gallium. Earth Sci Rev 150:95-101

Qin S, Zhao C, Li Y, Zhang Y (2015b) Review of coal as a promising source of lithium. Int J Oil Gas Coal Technol 9(2):215-229

Querol X, Fernández-Turiel J, López-Soler A (1995) Trace elements in coal and their behavior during combustion in a large power station. Fuel 74:331-343

Ramme BW et al. (2008) Separation of cenospheres from fly ash. US Patent No. 0190327A1

Ramme BW et al. (2011) Separation of cenospheres from fly ash. US Patent No. 8074804B2

Ramme BW et al. (2012) Separation of cenospheres from fly ash. US Patent No. 0050519A1

Ramya SS, Deshmukh VU, Khanderkar VJ, Padmakar C, SuriNaidu L, Mahore PK, Pujari PR, Panaskar D et al (2013) Assessment of 
impact of ash ponds on groundwater quality: a case study from Koradi in Central India. Environ Earth Sci 69:2437-2450

Rao RB, Chattopadhyay P, Banerjee GN (1999) Removal of iron from fly ash for ceramic and refractory applications. Magn Electr Sep 10:21-27

Reynolds RE et al. (1979) Process for Recovering aluminium and other metal values from fly ash. US Patent No. 4159310

Russ JJ et al. (1978) Process for recovering mineral values from fly ash. US Patent No. 4130627

Russ JJ et al. (1985) Method for separating and recovering silica, alumina and iron from fly ash, minerals ores and mine tailings. US Patent No. 4539187

Scharifker B et al. (2009) Process to recovery vanadium contained in acid solutions. US Patent No. 7498007B2

Seidel A, Zimmels Y, Armon R (2001) Mechanism of bioleaching of coal fly ash by Thiobacillus thiooxidans. Chem Eng J $83: 123-130$

Seredin VV (1996) Rare earth element-bearing coals from Russian Far east deposits. Int J Coal Geol 30:101-129

Seredin VV (2012) From coal science to metal production and environmental protection: a new story of success. Int J Coal Geol 90-91:1-3

Seredin V, Dai S, Sun Y, Chekryzhov IY (2013) Coal deposits as promising sources of rare metals for alternative power and energy-efficient technologies. Appl Geochem 31:1-11

Shabtai J et al. (1993) Extraction of metal oxides from coal fly ash by microorganisms and a new microorganism useful therefor. US Patent No. 5231018

Shiroto Y et al. (2003) Production of high purity vanadium compound from vanadium-containing carbonaceous residues. US Patent No. 6652819B2

Sierra-Alvarez R (2009) Removal of copper, chromium and arsenic from preservative-treated wood by chemical extraction-fungal bioleaching. Waste Manag 29:1885-1891

Sommerville R, Blissett R, Rowson N, Blackburn S (2013) Producing a synthetic zeolite from improved fly ash residue. Int $\mathrm{J}$ Miner Process 124:20-25

Soong Y, Schoffstall MR, Gray ML, Knoer JP, Champagne KJ, Jones RJ et al (2002) Dry beneficiation of high loss-on-ignition fly ash. Sep Purif Technol 26(2-3):177-184

Sparton Res Inc. (2007) First yellowcake produced from Xiaolongtang coal ash, China. http://www.spartonres.ca/pressreleases/ PR2007Oct15.htm. Accessed 10 April 2014

Styron RW et al. (2000) Method of removing carbon from fly ash. US Patent No. 6068131

Tolhurst L (2015) Commercial recovery of metals from coal ash. In: World of coal ash (WOCA) conference in Nashville, May 5-7. http://www.flyash.info/

Torralvo FA, Fernández-pereira C (2011) Recovery of germanium from real fly ash leachates by ion-exchange extraction. Miner Eng 24:35-41

Toshiaki A, Akira S, Masutaka F (1998) Production of ammonium metavanadate. Eu Pat. No. JPH10251025

Ucurum M (2009) A study of removal of $\mathrm{Pb}$ heavy metal ions from aqueous solution using lignite and a new cheap adsorbent (lignite washing plant tailings). Fuel 88(8):1460-1465
US EPA (2005) Using coal fly ash in highway construction, a guide to benefits and impacts, EPA-530, K-05-002

US Environmental Protection Agency (1999) Technical background document for the report to congress on remaining wastes from fossil fuel combustion: waste characterization. EPA 530-R-99010. Science Applications International Corporation, San Diego, CA

Vassilev SV, Vassileva CG, Karayigit AI, Bulut Y, Alastuey A, Querol X (2005) Phase-mineral and chemical composition of feed coals, bottom ashes and fly ashes at the Soma power station, Turkey. Int J Coal Geol 61:35-63

Vitolo S, Seggiani M, Filippi S, Brocchini C (2000) Recovery of vanadium from heavy oil and orimulsion fly ashes. Hydrometallurgy 57:141-149

Wang T, Wang J, Burken JG, Ban H, Ladwig K (2007) The leaching characteristics of selenium from coal fly ashes. J Environ Qual 36:1784-1792

Wang B, Li Q, Wang W, Li Y, Zhai J (2011) Preparation and characterization of $\mathrm{Fe}^{3+}$ doped $\mathrm{TiO} 2$ on fly ash cenospheres for photocatalytic application. Appl Surf Sci 257(8):3473-3479

Wu C, Yu H, Zhang H (2012) Extraction of aluminium by pressure acid-leaching method from fly ash. Trans Nonferr Met Soc China 22:2282-2288

Xiang-yang C, Xin-zhe L, Qui-li Z, Hong-zhou MA, Hin Z (2010) Leaching vanadium by high concentration sulfuric acid from stone coal. Trans Nonferr Met Soc China 20:123-126

Xu M, Yan R, Zheng C, Qiao Y, Han J, Sheng C (2003) Status of trace element emission in a coal combustion process: a review. Fuel Process Technol 85:215-237

Xu X, Li Q, Cui H, Pang J, Sun L, An H et al (2011) Adsorption of fluoride from aqueous solution on magnesia-loaded fly ash cenospheres. Desalination 272(1-3):233-239

Yao ZT, Xia MS, Sarkar PK, Chen T (2014) A review of the alumina recovery from coal fly ash, with a focus in China. Fuel 120:74-85

Yao ZT, Ji XS, Sarker PK, Tang JH, Ge LQ, Xia MS, Xi YQ (2015) A comprehensive review on the applications of coal fly ash. Earth Sci Rev 141:105-121

Yavuz CT, Prakash A, Mayo JT, Colvin VL (2009) Magnetic separations: from steel plants to biotechnology. Chem Eng Sci 64(10):2510-2521

Zhang FS, Itoh H (2006) Extraction of metals from municipal solid waste incinerator fly ash by hydrothermal process. J Hazard Mater 136:663-670

Zhang Y, Talbott JL, Wiedenmann L, DeBarr J, Demir I (1999) Determination of germanium content in coal ash by wavelengthdispersive X-ray florescence spectroscopy and inductively coupled-mass spectrometry. JCPDS-International Center for diffraction data

Zyryanov VV, Petrov SA, Matvienko AA (2011) Characterization of spinel and magnetospheres of coal fly ashes collected in power plants in the former USSR. Fuel 90(2):486-492 